EXEMPLARIa Classica

Journal of Classical Philology

14, 2010, pp. 43-87

ISSN 1699-3225

LuCUBRationes PropertianaE ${ }^{1}$

GEORG LUCK

Johns Hopkins University

gluck2@jhu.edu

\section{SUMMARY}

This article presents some critical notes on the text of Propertius which stem from a reading of the recent edition by Heyworth (Oxford 2007). These personal reflections are the fruit of many years' contact with the elegies.

KEYWORDS

Propertius, textual criticism, elegy

\section{RESUMEN}

En este artículo se presentan unas notas críticas al texto de Propercio que surgen a raíz de la lectura de la reciente edición de Heyworth (Oxford 2007). Se trata de unas reflexiones personales fruto de muchos años en contacto con sus elegías.

Palabras Clave

Propercio, crítica textual, elegía

Fecha de recepción: 15/05/2010

Fecha de aceptación y versión final: 24/09/2010

The appearance of S. J. Heyworth's Oxford Text (2007), his volume of critical discussions, combined with a translation, entitled Cynthia (also OUP 2007), and the very thorough, perceptive review by Antonio Ramírez de Verger in BMCR (2009-07-23) have prompted me to look at the text of Propertius again and write down a few ideas. I have also consulted G. Giardina's new edition, with an Italian translation (Rome 2005, 2010²).

In addition, Brill's Companion to Propertius, edited by H.-Chr. Günther (Leiden-Boston 2006) has been a great help, especially the chapters by P. Fedeli, J. Butrica and R. Tarrant. I did not have an opportunity to consult Fedeli's commentary on B. II (with a new text) and Hutchinson's commentary on B. IV, but I recommend them to the reader as important new contributions.

${ }^{1}$ I am very grateful to Antonio Ramírez de Verger for a critical reading of my article, for adding valuable comments and for providing editorial help. I also with to thank the anonymous referees of Exemplaria Classica for their suggestions. Thanks are due to Guillermo Galán Vioque for his kind assistance. My colleagues at Johns Hopkins University, Hérica Valladarez and Michael Sullivan have helped me in many ways, especially by locating the epigram by Hedylus which seems to support a conjecture in Propertius 2.29.15. 
The reader will first find the text of P. Fedeli's Teubner edition (Editio correctior 1994, repr. 2006) because in this way the progress marked by Heyworth in some cases becomes more visible. Fedeli is still useful for the readings and references in his Apparatus criticus, and I am aware of the merits of his work, but his text is too conservative, just as Giardina's seems too bold. Whereas Giardina never hesitates to print his conjectures, Fedeli often tries to defend the paradosis with arguments that are not always compelling. But where is the via media? I can only try and show my own view of the poor shape of the paradosis and the remedies that have been proposed, offering a few new ones along the way.

This is not a review article. I simply wanted to write down a few ideas and test them against the new editions. There is still much work to be done. Heyworth's edition represents real progress, and its companion volume is a store-house of solid learning and sound judgement.

If one spends many years of one's life reading a poet one loves and admires, one almost inevitably changes one's mind about some problems in the text. As important new contributions - such as the books mentioned above - appear, one sees things in a different light. This certainly happened to me.

Before dealing with problems in the text, I ought to say something about the textual tradition of Propertius in general (cf. J. L. Butrica, The Manuscript Tradition of Propertius, Toronto 1984; "Editing Propertius", CQ 47, 1997, 176-208; H. C. Günther, Quaestiones Propertianae, Leiden 1997; Brill's Companion to Propertius, Leiden, 2006, pp. 2-65: Fedeli, "The History of Propertian Scholarship"; Butrica, "The Transmission of the Text of Propertius", and Tarrant, "Propertian Textual Criticism and Editing"). Looking at the latest published research I think there is a general consensus, but also a good deal of disagreement concerning details. I will try to give a rough sketch of what seems to be the consensus today.

There are reasons to believe that only a single copy of an ancient edition of Propertius, probably equipped with marginal notes, survived into the Middle Ages and was copied at least once in the $12^{\text {th }}$ century somewhere in France. The state of the paradosis suggests that this copy was made in a very careless manner. It may be considered the common ancestor of the only two medieval MSS. - N (s. XII) and A (c. 1230-50) - which we have, but through lost links it may have produced a few other descendants as well.

A not very homogeneous group of extant MSS. may be placed between the two medieval witnesses and the many later Renaissance copies. These are $\mathrm{F}$ (c. 1380), L (1421) and $\mathrm{P}(1423)$. There is really no strict dividing line, and if one looks at their age, $\mathrm{P}$ is only six years older than H.'s T (1427). Most of H.'s younger witnesses as well as G.'s Z could be called Itali, yet these editors assign capital letters to them and distinguish them from the 'stigma' group which H. defines as 'anyone's conjecture before 1600'. 
A few witnesses which were highly estimated by previous editors are now radically discarded. Here is a list of them, along with the names of their main sponsors: D = Daventriensis (Burman, Baehrens, Housman); V = Vaticanus Ottobonianus (Heinsius, Baehrens); Vo = Leidensis Vossianus (Burman, Richmond); Groninganus (Broukhusius, Lachmann). No one would blame these scholars for putting too much trust into a witness from which they were expecting important new insights. Personally, I do not think that they are totally worthless; in fact, they preserve, perhaps by conjecture, a few good readings.

The value of the Itali, also known as recentiores or deteriores, is difficult to assess. There are about 150 of them. Quite a few can be dated exactly, and sometimes the names of their scribes and former owners and annotators are known. Here we find the names of famous humanists: Petrarca, Coluccio Salutati, Antonio Beccadelli, G. G. Pontano, Lorenzo Valla, Pomponio Leto. These MSS. are, in a way, the predecessors of our printed editions in the sense that they are not faithful copies of a single earlier text but the products of deliberate editing. We now lump them together, but former editors cited them by the names of their owners, e. g. as Askewianus, Cuiacianus, Mentelianus, etc.

The scribes and owners of these texts were, at this time, mostly scholars and poets, and it was their ambition to create a satisfactory text from the inferior sources they had at their disposal. Relying on their knowledge of classical poetry and their own poetic practice, they corrected the text of Propertius, as they went along. Many of their corrections are very good (in fact, some of them occurred again to the great critics of later periods, such as Scaliger and Heinsius), but some of them are not. It is always possible that a humanist had access to a bona fide 'codex vetus', now lost, but most of their changes were probably made ope ingenii. They have to be judged purely on their merit, as if they were conjectures made today. Some editors seem to be too rigorous in rejecting humanist readings because they tend to trust the 'older' witnesses.

There is a slim but important indirect tradition, including Pompeian graffiti and two florilegia. Scholars generally agree that the indirect tradition, where it goes against our MSS., offers a better text, a fact which, in itself, highlights the poor condition of the direct paradosis.

\subsubsection{1-2}

nam modo Partheniis amens errabat in antris, ibat et hirsutas ille videre feras

Videre has been taken in the sense of adire, but editors seem to prefer ferire (Itali, Heinsius) or comminus ille (Palmer) which is a possibility (see 2.19.22 celer agrestes comminus ire sues; Ov. fast. 5.176 in apros/ au- 
det et hirsutas comminus ire leas), but it would involve a major change. $\mathrm{H}$ (eyworth) accepts ille ferire but also assumes a lacuna after v. 11, following Housman, while G(iardina) prefers agitare (Burman). Li(berman) shows that videre is unsatisfactory. He favors comminus ille and adds that Milanion is probably hunting in Atalanta's company. He calls ille ferire a 'weak conjecture'. What we need, in my opinion, is ciere (Baehrens) which is close to videre palaeographically and has the technical sense of agitare, 'to beat, to drive'; cf. Acc. trag. 494 cum $<e>$ somno in segetem agrestes cornutos cient; Lucr. 5.1251 saepire plagis saltum canibusque ciere. The Hellenistic poet whom Propertius follows lets Milanion play the inferior role of a beater so he can be near the beloved, while she, as the hunter, plays a role more appropriate to a hero. A referee who likes ciere tentatively suggests illaqueare.

\section{2 .25}

non ego nunc vereor, ne sim tibi vilior istis

The poet compares Cynthia, not himself, to the heroines of myth. This makes the paradosis suspicious. To take ista as 'quae modo dixi' seems more or less a 'Verlegensheitslösung'. The poet knows that Cynthia is just as enchanting as all these beauties of the past. This would seem to exclude sis mihi (Itali, Scaliger, Passerat). What should be considered is sis tibi (Wehle). H. changes non to ergo which seems unnecessary (cf. 1.6.1; 19.1) and keeps sim tibi. G. prefers sis mihi. Li. mentions Jacob's verear ... sim ... istis?

\section{$1.3 .7-8$}

talis visa mihi mollem spirare quietem

Cynthia non certis nixa caput manibus

Read probably consertis (Guyet) which is explained as 'pectinatim'. This could be due to wrong word division and the misunderstanding of a prefix, both frequent sources of corruption in this paradosis. H. keeps the vulgate and refers (C., p. 16) to a work of art, as if her 'restless hands' (his translation) could be seen on it. And how do restless hands agree with her soft sleep? G. also has no objections to non certis.

\subsubsection{3-8}

et quamvis duplici correptum ardore iuberent hac Amor hac Liber, durus uterque deus, subiecto leviter positam temptare lacerto osculaque admota sumere et arma manu, non tamen ausus eram dominae turbare quietem, expertae metuens iurgia saevitiae 
Gronovius' ad ora (Obs. IV 6) is such a neat correction of the bizarre et arma that we hardly need any arguments. He kisses his hand and then touches her lips, as Burman explained. For expertae we should probably read expertus (cf. J. P. Sullivan, WS 74, 1961, 108); cf. 2.34 .3 expertus dico. This is one of the many cases (already detected by Lachmann; see C., p. 23 and n. 19) where the ending of a word was adapted to agree with the last word of the line; see below on 1.20.14; etc. Experte is found in the Aldina and was conjectured by Markland. H. keeps et arma (see C., p. 17), while G. follows Gronovius who also corrected arma to ora in 4.4 .34 (accepted by H. and G., but not by F.). In 3.13.54 the Groninganus has in ora for in arma ( $\omega)$. Li. points out the metrical difficulties in v.16, as transmitted, but he is not comfortable with Gronovius' proposal and tends to prefer osculaque ... certa which he attributes to Scaliger.

\subsubsection{5-6}

dum me iucundis lapsam Sopor impulit alis. illa fuit lacrimis ultima cura meis

F. lists no alternatives to cura, but we have a choice between creta (Scal., Guyet; cf. 4.2.58 haec spatiis ultima creta, where meta is a humanist conjecture) and meta (Askewianus, Heins. ex coni.). CRETA may be a little closer to CVRA palaeographically. Cynthia says that she finally stopped crying and fell asleep. That is all. But cura can also express this, as Li.'s elegant translation shows: "voilà ce qui fut le dernier objet de mes soucis, à moi qui pleurais." He doubts that cura can mean 'remedy' and that the dative can take the place of the genitive one would expect. He does not mention creta and meta. H. leaves cura and translates (pp. 20; 519) 'that was the final cure for my tears'. As far as I know, cura can mean the treatment of a sick person, but not, per se, as 'cure' in English, the successful treatment, the remedy that really works. G. also keeps cura which he takes as 'pensiero'. Danilo Piana points out to me that cura can be taken in the usual senses of 'love' or 'care' or 'worry', describing her emotions before she falls asleep. In that case, $u l$ tima might refer to 44 externo ... in amore moras, and 2.32.31 shows what externus amor means; cf. also 2.19.16.

\section{$1.4 .5-8$}

tu licet Antiopae formam Nycteidos, et tu

Spartanae referas laudibus Hermionae, et quascumque tulit formosi temporis aetas;

Cynthia non illas nomen habere sinat

Read probably Spartanam ... Hermionen (Lipsius ex coni.) ... vel ...famosi (Struve, Baehr.) ... sinet ( $\mathrm{V}^{2}$ alii, Dousa fil.). Formosum tempus can- 
not really mean tempus formosarum, and F.'s reference to Ov. fast. 4.129 is totally misleading, for there it means 'beautiful weather'. What the poet had in mind is probably aetas fabulosa = 'the age of myth'. Formosum was influenced by forma (v. 5). In 4.4.32 famosa ( $\omega$ ) was corrected to formosa in the Itali. The future, sinet, seems needed, because the poet speaks of a judgement reached after comparing all these beauties. G. adopts famosi but keeps the genitives in v. 6 as well as sinat, while H. prints the vulgate throughout the two couplets. Li. objects to famosi, pointing out that it means 'fameux', not 'fabuleux', and he would prefer melioris.

\section{$1.4 .13-4$ \\ ingenuus color et multis decus artibus et quae gaudia sub tacita ducere veste licet}

Here, multis ... artibus is right and should not be touched. Cynthia's many accomplishments are real (nullis $\mathrm{P}^{2}$, Askewianus, Scioppius seems to be influenced by the theme of 1.2). We should compare 2.3a.9ff where there is the same transition from her beauty to her various gifts, there called $m u$ nera (v. 25), dona (v. 27) and bona (ibid.). She can dance, sing, write poetry (17ff). Ov. am. 2.10.5-6 utraque formosa est, operosae cultibus ambae, / artibus in dubio est haec sit an illa prior also combines beauty and achievements in his praise. In the context of 1.4, her achievements clearly include her techniques of love-making; cf. 2.6.32 orgia sub tacita condita laetitia. In the pentameter, dicere ( $\omega)$ does not make sense, and ducere (Itali) is not better. Heinsius' discere seems to be the solution. I cannot find it in his Adversaria, but it is attributed to him first by Kuinoel. There he seems to accept Guyet's proposal. Because Cynthia is so good at making love, this is an art that can be learned from her. H. prints discere, but accepts two awkward conjectures, motis (Goold) ... artubus (Marcilius), which would restrict her many talents to one. But she is much more than just an accomplished dancer. $\mathrm{Li}$. is right, I think, to sense in multis ... artibus an allusion to Cynthia's 'savoir-faire' in the techniques of love-making. This would confirm discere in the next line. H. prints decor (Itali; Bentley on Hor. carm. 4.13.17), but decus is fine; it corresponds to the last word of the poem (deus codd.), as emended by Kraffert; see below. G. writes nullis $\left(\mathrm{P}^{2}\right)$ datus (G.) artibus ... sumere (G.) nocte (Faltin, Palmer).

\section{4 .17}

non impune feres: sciet haec insana puella

Read, perhaps, haec, insane, puella with the Editio Gryphiana (1551) and Kuinoel (1805, dub.). Cf. on 1.5.3 below. Actually, as a referee points out, sciet hoc (H. ex codd.) is better than sciet haec. Both G. and H. keep 
insana, and Li. takes it as proleptic: "my mistress will be furious when she hears this."

1.5.3

quid tibi vis, insane, meos sentire furores?

Read meae (sc. puellae; cf. tuae in 1.9.22; 3.14.22), as proposed by Hemsterhuys (in Burman's edition, p. 925) and accepted by Lachmann, Housman and others. This use of the possessive pronoun as a noun, also attested in Greek, seems to be misunderstood by scribes and scholars in 4.6 .60 (see below). But see, e. g., Prop. 3.8.22 me doceat livor mecum habuisse meam; Tib. 2.3.77 (81) si clausa mea est, si copia rara videndi; Hor. carm. 1.25.7 me tuo longas pereunte noctes, / Lydia, dormis? On insane cf. 1.4 .17 above. F.'s objection that furores must mean Propertius' insane love for Cynthia is one of his many attempts to save the paradosis, even where it cannot be saved. I would not call this "Korruptelenkult" (a term coined by B. Axelson), but it comes close to it. This seems to be another one of the cases where the ending of the last word of the line influenced the preceding adjective or pronoun which belongs to it. The furor of which Cynthia is capable, her saevitia (1.3.18), her dementia (cf. 1.8.1, but probably not 1.4.17) are well documented throughout Book I. Guyet changes meos to suos, and Heinsius accepted this. The whole poem, addressed to Gallus, is really a continuation of 1.4 which is addressed to Bassus. Both friends (apparently belonging to the group of amici in 1.1.25) are trying to talk the poet out of his devastating passion, using different arguments (perhaps in poems addressed to him), but he rejects their advice. Meae became meos under the influence of the last word of the line, as often (see on 1.3 .18 etc.); perhaps the $s$ - of sentire also played a role. H. leaves meos in the text; from G.'s app. crit. it appears that feros and meros are old variants for meos which he also prints. Li. considers meos more satisfactory than meae which, to me, is one of Hemsterhuys' best conjectures.

1.5 .12

\section{illa feros animis alligat una viros}

I still think that we should write ferox animis (AJPh 100, 1979, 75). Ferox is found in the Dresden MS, as a referee points out. Who are the feri viri she attaches to herself? Propertius? One of his friends? But that is not the way he portrays himself. Both as a lover and as a poet he would like to be seen as blandus, while Cynthia's ferocia is evident in this poem as well as in the preceding one. For ferocia animi cf. Sall. Catil. 61.4; for ferocia in a woman cf. Tac. ann. 2.72.1. Ferox became feros because of the last word, viros. There is a similar case in 3.2.7 (see below). H. and G. accept ferox, while Li. who considers it also lists other possibilities. 
1.6.27

\section{multi longinquo periere in amore libenter}

In this context, longinquo strikes one as an error for longaevo, suggested by Fontein who surely deserves to be saluted as one of the best emendators of Propertius. Distance and space have nothing to do here; it is all a matter of time. Heinsius showed that longinquus can mean longus, diuturnus, but not that it can have this meaning with amor. Propertius leaves long trips to his friends and prefers to stay in Rome; this is where his militia and his hardships are, for years to come, if that is what the Fates have ordained for him (cf. 29-30; 2.13b.47). G. keeps longinquo, H. (pp. 25-6) follows Fontein, and $\mathrm{Li}$. welcomes the change because it removes the 'ambiguity' of the paradosis.

\subsubsection{5-6}

te quoque si certo puer hic concusserit arcu, +quod nollim nostros eviolasse+ deos,

It is regrettable that the recent editors have not seen the merit of what is, to me, one of W. A. Camps' best ideas,

(quod nolim nostros, heu, voluisse deos)

Camps (who followed Lipsius, Guyet and Heinsius) became aware of the fact (see his note, 1961, ad loc.) that, in this paradosis, the interjection heu sometimes appears in an abbreviated form, as $e$ or $e ́$ or $\grave{e}$, for instance in 1.19.22 where heu nostro (Hertzberg) seems to have become e nostro; along the same lines, the Aldina (1515) offers ei nostro, and Richmond proposed ah! nostro, but F. prints a nostro, following the Itali. In 2.12 .15 editors now print Muretus' heu for é (or something like it). In 4.10.27 heu Veii veteres, Lütjohann's emendation for $e$ or $e t$, is generally accepted. In our passage, $\mathrm{H}$. cites the emendation but ascribes it to Markland and prints te violasse, while G. inflicts quod nolis nostros evoluisse iocos on Propertius. In v. 15 percus serit (Itali, Lipsius, Guyet, Heins., Valckenar. on E. Hipp. 1303) is accepted by $\mathrm{G}$., but not by $\mathrm{H}$. This seems to be a case of the wrong prefix. Camps' note is very instructive. Liberman is in favor of per-.

\subsubsection{5-6}

tu cave nostra tuo contemnas carmina fastu: saepe venit magno faenore tardus Amor.

Rossberg who more than once anticipated Housman, saw that amor cannot be right. Propertius thinks about his poetry and about his reputa- 
tion as a poet, not about love or the god of love (why F. capitalizes amor is a mystery). We have to read, with Rossberg, honos or honor. It is an easy change. $(H) O N O S$ has been corrupt to onus in a closely related passage, 3.1.21-2

$$
\begin{aligned}
& \text { at mihi quod vivo detraxerit invida turba, } \\
& \text { post obitum duplici faenore reddet honos, }
\end{aligned}
$$

where the error has been corrected in the Itali. In 1.7, the verse ending serus amor (20) may also have played a role. Note that in Cic. Sull. 12 and in the Ciris 109 forms of amor and honor appear as vv. ll. A similar corruption occurs in Ov. met. 5.526: Jupiter tries to make the abduction of Proserpina acceptable to her mother, Ceres. It is by no means a mésalliance, he says; on the contrary,

\section{si modo nomina rebus}

addere vera placet, non hoc iniuria factum, verum honor est, neque erit nobis gener ille pudori.

Here, all the MSS. have amor for honor, but it is quite clear from the story that amor does not describe Proserpina's feelings. We need a contrast to iniuria, 'insult', and pudor, 'disgrace', and that can only be honor. Dis may not be very high up in the divine hierarchy, but he would nevertheless make a most respectable son-in-law. In Ovid, amor was emended by Schepper (Burman II, 363-4; cf. Exemplaria Classica 12, 2008, 52-3 where I mention G. Liberman's objections (per litt.) against the change in Propertius; in his commentary he transposes the distich after v. 14, following Fischer (1863) and Otto (1885). G. prints Honos, H. honos.

\subsection{7-8}

tu pedibus teneris positas fulcire pruinas, tu potes insolitas, Cynthia, ferre nives?

Fulcire is a strange verb in this context, and F.'s explanation 'Cynthiae pedes nivem premunt eamque sustinent' might be called outlandish, if the $O L D$ (p. $743[2])$ did not actually squeeze the meaning 'to tread' from the dubious MS. reading in our passage (not supported by Celsus 1.17 .5 where the context is entirely different). F. mentions sulcare $\left(\mathrm{P}^{2}\right.$, Beroaldus) and calcare (Passerat, Heins., Ayrmann) but pays no further attention to them. Both G. and H. print calcare. Incidentally, Lachmann was impressed by Hemsterhuys' defense of fulcire and called calcare 'rash', but see, e. g., Ov. met. 2.852-3. Hemsterhuys' note can be found in Burman, Addenda, 927. It seems to me that sulcare which is close to the 'ductus litterarum' should at least be mentioned. It seems that fulcire was also influenced by the false 
reading ruinas (N A F P) which once appealed to editors. But it could also be the other way around, as Li., following Housman, points out.

\subsubsection{3}

\section{nunc mihi summa licet contingere sidera plantis}

In this form, the hyperbole seems to border on the grotesque, but only if we imagine the speaker hanging upside down, his feet somehow attached to the stars. It is very tempting to read palmis (Scaliger ex Italis, ut vid., Lipsius, Guyet, Heins.), but Broukhusius vigorously opposed the change, because he remembered Catull. 66.69 sed quamquam me nocte premunt vestigia divum. Propertius may compare himself to a deity who walks on top of the stars. H. (C., pp. 39-40) shows that touching the stars with one's hand or head is also used with the same connotation, and he prints palmis; so does G. The last word may have been difficult to read. See on 1.20.27. Li. observes that Propertius would not have chosen contingere as a verb, if he had written plantis.

\subsection{0 .15}

possum ego diversos iterum coniungere amantis et dominae tardas possum aperire fores

Read probably divisos (Beroaldus, Passerat ex Italis); cf. 1.12.3; 10; 2.7.3; 33.5-6 quae dea (sc. Isis) tam cupidos totiens divisit amantis, / quaecumque illa fuit, semper amara fuit. Forms of diversus and divisus are often confused in the MSS. As often, the so-called parallels cited by F. do not prove what he wants them to prove, i. e. that diversus here must mean discors: (1) Hor. sat. 1.5.29 aversos ... componere amicos says nothing about diversus; (2) Paneg. Mess. 45 diversi (divisi unus Vaticanus, fort. recte) ... inconstantia vulgi is of doubtful value; (3) Lucan. 6.783 diversi simply means 'others'; (4) Tac. ann. 6.22 sapientissimos veterum ... diversos reperies refers to philosophical opinions. None of these passages invalidates a conjecture which establishes the sense we expect with a minimal change. We need a contrast to coniungere, and that is furnished by divisos. In the pentameter read perhaps surdas (Heins. dub.) for tardas; the point is probably not that the door opens slowly; the point is that it does not open at all, because the janitor is deaf to the lover's complaints; cf.1.16.18 quid mihi tam duris (surdis Francius) clausa taces foribus; 4.5.47-8 ianitor ad dantis vigilet: si pulset inanis, / surdus in obductam somniet usque seram. But tardas is suitable if one imagines a delay after which the door is suddenly opened, as if by magic. Incidentally, Heinsius' note on 1.8.41 (Adversaria, p. 663) makes one wonder whether forms of surdus should not be substituted to forms of tardus in 1.1.17;37; 8.41 (Heins. ex coni.). H. adopts surdas (C., p. 
49), but keeps diversos (ibid.), while G. keeps diversos ... tardas. Li. seems to have a slight preference for divisos but is not convinced by surdas.

\subsubsection{8-9}

multis ista dabunt litora discidium, litora quae fuerant castis inimica puellis

To conjure up a 'gnomic future' in order to justify dabunt, as F. does, looks like a desperate attempt at defending a notoriously unreliable textual tradition at all costs. The obvious correction, dabant, is found in $\mathrm{Vo}^{2}$ and a Bononiensis, and it was accepted by Burman, Lachmann and others. The Vossianus 117 may not be a very good witness, but its corrector obviously knew Latin. In this paradosis, endings are corrupted so often, and $a$ is so frequently read for $u$ that a small change like this does not have to be explained at great length. Lachmann printed dissidium, rejecting discidium, but cf., e. g., 2.24c, 32; OLD s. v. 'discidium'.

In the following line read fuerunt (Scaliger, Livineius). See on 2.8 .10 below. The poet does not refer to a mythical past: Baiae as the fashionable resort in his own time has a bad reputation. Other resorts should also be avoided by lovers (see $1.20 .7 \mathrm{ff}$ ), but Baiae is especially dangerous. $\mathrm{H}$. does not reject dabunt but prints fuerunt in the next line (see C., pp. 56-7). G. edits dabunt ... fuerunt. Li. does not object to dabunt but favors fuerunt and explains the mechanism of the error.

\subsubsection{3-4}

haec ego non rumore malo, non augure doctus: vidi ego: me quaeso teste negare potes?

Propertius lists three different sources of information, ranked according to their degree of credibility: (1) rumor; (2) prophecies; (3) himself as an eyewitness. It does not matter whether the rumor is good or bad $(2.23 .24$ is different); what matters is only whether it can be trusted or not. Haupt's aio for malo is weak, as F. points out, but Francius' vago seems excellent to me. We should remember Ovid's wonderful description of the rumors floating around in the house of Fama, in met. 12.53-5 veniunt, leve vulgus, euntque/ mixtaque cum veris passim commenta vagantur/ milia rumorum confusaque verba volutant. The verb vagantur would seem to lend support to Francius' suggestion. G. and H. do not mention vago, but Li. supports it by a number of parallels, e. g. Ov. met. 11.667 non ista (ficta Heins.) vagis rumoribus audis. Incidentally, Rossberg's haec non sum also occurred to Housman; see Heyworth, in: Butterfield and Stray (edd.), A. E. Housman: Classical Scholar, London 2009, 16. This is not the only coincidence of this kind. 


\subsubsection{3-4}

nec sic caelestem flagrans amor Herculis Heben sensit ab Oetaeis gaudia prima rogis

It is a pleasure to note that F. prints this couplet as it was restored by Scaliger and Schrader from the corrupt MS. readings in ... iugis $(\omega)$ and that he avoided the errors of Beroaldus and Enk. One could consider taking gaudia prima as an apposition, placing the two words between commas. Amor Herculis means 'Hercules in love', and Hebe is his first joy after becoming immortal. H. also opts for $a b$... rogis. G. writes caelestis flagrans amore [sic] Herculis Hebe [sic] which must be a misprint (see his p. 20), but even what he intended, caelestis, flagrans amor Herculis, Hebe seems strange. Li. supports Schrader's proposal by Stat. silv. 3.1.7; 4.6.53.

\subsubsection{9-20}

Hypsipyle nullos post illos sensit amores, ut semel Haemonio tabuit hospitio

Others may feel differently, but to me nullos ... illos produces an unpleasant sound effect. Once again, a scribe seems to have anticipated the ending of the last word of the line. In this case, he was also, perhaps, influenced by the ending of nullos, and the ending of illos may have been affected by the $s$ - of sensit. Burman suggested post illum (i.e. after Jason), and it is such an easy change that it should be at least mentioned in the app. crit. of a modern edition. G. leaves illos, H. accepts illum (see C., p. 67-8), Li. is aware of the conjecture but does not assess its value.

\subsubsection{3-4}

has inter gravibus cogor deflere querelis supplicis a longis tristior excubiis

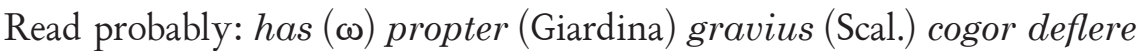
querelas (Scal.)/ supplicis a longis tristior excubiis. Cf. 3.10 .28 where gravius (Beroaldus, Guyet, accepted by H., but rejected by F. and G.) also became gravibus. Here, in 1.16, the door is moved more deeply by the particular complaints of one rejected lover (anticipating vv. 17-44) and feels more sadness because of the long hours he wasted in front of the house. Gravius and tristior correspond to each other. Haec (cod. vetus Passeratii) has no clear reference, but has goes with querelas which may have been become querelis because of gravibus, one corruption creating another. H. prints has ... gravibus ... querelis / ... a, and G. gives us hanc propter gravibus ... querelis, introducing two of his own changes. Actually, his propter is quite attractive, but with has querelas, not with hanc ... querelis. Liberman's 
discussion of this passage is particularly enlightening. He calls F.'s text "un charabia opaque" and takes $a$ as the preposition (see my note on Ov. trist. 4.3.36), not the interjection (Passerat, Broukh., Heins. ex codd.) which is better, especially if we accept propter, because the two prepositions indicating a reason would correspond to each other, just like gravius and tristior.

\subsection{9-10}

quid tantum merui? quae te mihi carmina mutant? an nova tristitiae causa puella tuae?

The poet wants to know what he did to make Cynthia angry. On tristitia $=$ ira, inimicitia cf. 1.6.10. To take carmina as carmina magica (F. ad loc., following Beroaldus and Passerat) is out of the question. Whatever it was, it had to come from him, not from any witches. Read crimina (Puccius ex cod., corrector Italus ap. Perreium, Pocchus, Lipsius [Lect. Ant. IV 11] ex coni.). The ghost of Cynthia herself tells him what she had in mind: celo ego perfidiae crimina multa tuae (4.7.70). Crimina agrees with notam (8) in the sense of 'stigma'; it also reinforces the concept of merui: cf. Tac. hist. 3.78 Antonius praepostero obsequio ... crimen meruit. F. cites Leo and Solmsen who support crimina but keeps carmina in his text. One should remember that crimina does not always mean 'crimes', but often 'reproaches, charges, accusations', i. e. something that exists in Cynthia's mind, not something he actually committed. H. and G. print crimina which is also the reading preferred by $\mathrm{Li}$. who takes it to mean 'accusations', i. e. 'slanders of enemies', following Paley.

\subsubsection{1-2}

a quotiens teneras resonant me verba sub umbras scribitur et vestris Cynthia corticibus

Here some major damage has to be repaired, as Lachmann saw. Propertius addresses trees which were (perhaps) once human beings or nymphs and were transformed because of some great passion (see A. Hollis, in: Brill's Companion to Propertius, 106-7; P. Knox, ibid., 138-9). Therefore they know how he feels. At one point in the transmission of the text, corticibus seems to have lost its proper epithet, teneris (proposed by Heins.) or rather it was moved to the preceding line where it managed to push out the proper epithet of umbras. According to Guyet, Schrader and Koppiers (1771), the distich in its original form looked like this

a quotiens vestras resonant mea verba sub umbras scribitur et teneris 'Cynthia' corticibus 
This was accepted by Lachmann and others, but would one not expect vestra ... sub umbra (Liberman) or vestris ... sub umbris? H. accepts tenera ... sub umbra (Hall) and vestris ... corticibus (N T Y C). Cf. C., pp. 812. G. introduces another conjecture, tenues (already proposed by F. G. Barth, 1777), for teneras, but this is not better than Guyet's virides. Li. accepts the switch of epithets and furnishes an ingenious explanation of the error.

1.19.21-2

quam vereor, ne te contempto, Cynthia busto, abstrahat a nostro pulvere iniquus Amor

Read probably heu (Hertzberg) for $e$ ( $\omega), a$ (Itali) or $a h$ (Richmond). See above on 1.7.16 . H. and G. prefer $a$, but G. changes amor to amans, a kind of acte gratuit.

1.20.9-10

sive Gigantea spatiabere litoris ora, sive ubicumque vago fluminis hospitio

In v. 9 read probably Gigantei (Itali), in v. 10 vagi (D V Vo, Auratus, Passerat, Heins.). For Gigantei ... litoris cf. 1.11.2 qua iacet Herculeis semita litoribus. For vagi fluminis cf. 2.19 .30 vaga muscosis flumina fusa iugis. F. speaks of an 'enallage', but we seem to have two more cases (in the same couplet) of the attraction of an epithet to the last word of the line. Both G. and H. print vago. H. gives us Gigantei while G. keeps the vulgate. Li. reminds us of Shackleton Bailey's support of Gigantei (see Propertiana, 56), and this conjecture was also accepted by George Goold. Li. is in favor of vagi but suspects a major corruption in the line.

\subsection{0 .12}

(non minor Ausoniis est amor Adryasin)

Adryasin is Struve's conjecture for adriacis ( $\omega)$, and it has been accepted by editors, but Adryas must be a tree nymph, and the word itself is weakly attested in Greek and Latin. Actually, the poet is thinking of Italian water nymphs, i. e. of Roman beauties who visit fashionable bathing resorts, such as Baiae, and are always ready to seduce handsome young men. (See Camps, in his Commentary, 1961, 93, who attributes this very plausible view to a friend). What one would expect is Lachmann's Hydriasin which is well attested (see his note). Accordingly, we would also need Ephydriasin (Baehr.) in v. 32 and Hydriades (Unger) in v. 45 , it seems to me. G. and H. (see C., pp. 88-90) read Adryasin (12) ...Hamadryasin (32) ... Dryades (45). It is true that the poets do not always distinguish between water nymphs and tree 
nymphs (Li., referring to Housman on Lucan. 7.871), but here the point of the whole poem is lost if these ladies are not clearly defined as creatures of the water.

\subsubsection{3-4}

ne tibi sit duros montes et frigida saxa,

Galle, neque expertos semper adire lacus

I see no way of explaining expertos ... lacus, and F.'s references are only designed to illustrate neque expertos $=$ et inexpertos. Read experto (Livineius). The $-s$ was added by dittography or by the tendency of a scribe to adjust a word ending to the ending of the last word of the line; see on 1.3.18; 20.10. Experto goes with tibi and must mean 'after what you have experienced', for this sort of thing probably happened before, and Propertius reminds him (see v. 51 monitus; cf. on 1.3.18 above). H. and G. leave expertos which, I suppose, could be taken as passive ( $\mathrm{Li}$. who compares 1.2.5 mercato; 19.6 oblito).

Two (in my opinion) outstanding emendations allow us to understand and appreciate the ending of this poem. As usual, I first print F.'s text:

\subsubsection{9-52}

cui procul Alcides iterat responsa; sed illi nomen ab extremis montibus aura refert.

his, o Galle, tuos monitus servabis amores, formosum Nymphis credere visus Hylan.

Read in v. 49 with Fontein and Huschke ter 'Hyla' respondet, at (or: responsat, at) illi and in v. 52 with Palmer formosum ni vis perdere rursus Hylan. F. mentions the second conjecture, as modified by Housman (rusus for rursus) but feels no need to change anything. G. rewrites the two couplets extensively: quem procul Alcides rogitat ... Nymphis credere nil sit. H. accepts Fontein's reading in v. 49, but prints nymphis credere rursus in v. 52, postulating a lacuna of two lines before 51 and 52 . See $C$., p. 93-4. I prefer Palmer's neat solution. Li. calls Fontein's solution 'géniale' and is aware of the advantages of Palmer's proposal.

\subsection{4}

\section{Iuppiter, ignosco pristina furta tua}

This pentameter has a weak ending, I think. Read probably tibi for tua with Heinsius who refers to Passerat's defense of ignosco (ignoro N F P alii). Tua was probably influenced by furta. It is interesting that, in Enk's 
paraphrase, cited by F., tibi appears along with tua: 'ignosco tibi, Iuppiter, pristina furta tua; nam tam formosa est Cynthia, ut optime intellegam te olim puellas mortales rapuisse.' G. keeps tua, H. (p. 114) accepts tibi.

\section{3a.17}

quantum quod posito formose saltat Iaccho

The context seems to require cum (Lachmann; see his note), probably written QVOM; cf. 19 et quantum Aeolio cum temptat carmina plectro. Otherwise, we would have to change cum in v. 19 to quod (Guyet). It should be either cum ... cum or quod ... quod. But because of si in v. 15 and cum in v. 21 (which cannot be changed to quod; see below), cum is more likely in v. 17. Both G. and H. see no problem with quod ... cum ... cum, but H. at least cites the two conjectures.

\section{3a.23-4 \\ non tibi nascenti primis, mea vita, diebus candidus argutum sternuit omen Amor?}

Here, as usual, the indirect tradition (Macrob., GLK V 625, 15) is right. Candidus became ardidus (vel sim.) in the direct tradition, probably because the first letter of the first word was lost. (The explanation of the error was already offered in the Cambridge edition of 1702; I know this book only through the references in F. G. Barth's edition, 1777, who treats it with great respect). This disposes of Beroaldus' fervidus and of Heinsius' aureus. There is no need to document candidus in the sense of 'favorable', said of a deity (see $O L D$, p. 265, [5b; 7a]. Should one also change argutum to argute (Heins., 'fort. recte' F.)? Probably not: see Cic. div. 2.29 sunt ... qui vel argutissima haec exta esse dicant. G. prints fervidus ... argutum, H. (p. 123) edits $\operatorname{nam}(\mathrm{Q})$... candidus ... argutum.

\section{$2.3 \mathrm{~b} .45-6$}

I still think (cf. my edition, Zürich 1996, 62) that this couplet marks the beginning of a new poem which originally included $\mathrm{nr}$. 4 . This would give us an elegy of $32(10+22)$ lines. Schrader and Lachmann, following the Aldi$n a$ of 1502 , connected 2.3b.45-54 with 2, 4 . But no matter how we separate the poems, the text printed by $\mathrm{F}$. and others seems wrong:

his saltem ut tenear iam finibus! ah mihi si quis acrius ut moriar, venerit alter amor! 
Years ago (cf. my edition, Zürich 1996, 62 and 369) I defended Tyrrell's easy change of ut tenear to aut tenear which allows us to keep aut mihi (N P F man.4) in the same line. F. replaces this by ah (Puccius); others have preferred (h)ei (Lachmann), at (Paley) or an (F). In v. 46 acrior (Itali) seems to be an improvement over acrius $(\omega)$ which F. tries to defend by a reference to Plaut. Trin. 540 where swine are said to die a very painful death from an acute throat infection. This, I am sorry to say, does not work, nor is Giardina's objection (1977, p. 126) at all convincing: 'qui possit fieri, ut alter post acerrimam Cynthiam [sic] acrior poetae videatur amor?' This is exactly what the poet has in mind. His next love - if there ever will be one - will have to be so strong that it could kill him. So far, his love for Cynthia, overwhelming as it is, has not destroyed him completely, but a new passion which would obviously separate him from Cynthia, could only lead to his death. For acer amor cf. Verg. Aen. 12.392 iamque aderat Phoebo ante alios dilectus Iapyx/ Iasides, acri quondam cui captus amore/ ipse suas artis, sua munera, laetus Apollo/ augurium citharamque dabat celerisque sagittas. Here we have a powerful description of what acer amor can do - even to a god! This testimony counts, perhaps, a little more than the dying swine in Plautus. I still believe that we should read, with the proper punctuation:

his saltem aut tenear iam finibus aut mihi, si quis, acrior, ut moriar, venerit alter amor.

Here, ut moriar perfectly well explains acrior. G. prints $u t \ldots$ at ...ne ... acrius, and H. (pp. 125-6) has a long, involved discussion; in his OCT he leaves aut the word after saltem altogether and reads ei ... acrius. He prints three dots before vv. 45 and 47 , making the couplet float in a kind of no man's land, a kind of treatment that surely does not do a service to the poet - or to the reader.

\subsection{5}

nec quae deletas potuit componere Thebas, Phryne

Here we should, perhaps, pick a plausible conjecture. The paradosis offers delectas which was changed to deletas by a younger hand in $\mathrm{N}$; but we also have a choice between deiectas (Gebhard) and disiectas (Schrader, Emend. C. VI, p. 121), both better than deletas (defended by Broukhusius), because the $c$ in delectas is likely to be part of the original reading. As a contrast to componere, we might find deiectas more appealing; see also 2.8.10 et Thebae steterunt (Itali, Scaliger : -ant $\omega$ ), but Val. Max. 1.5.1 urbe a Gallis disiecta would confirm Schrader's suggestion. H. (pp. 134-5) makes a good case for deiectas; G. leaves deletas in the text. 


\subsubsection{1-2}

ah gemat in tenebris, ista qui protulit arte turpia sub tacita condita laetitia

F. accepts Fontein's emendation of terris. As often, a longer word has been contracted into a shorter, look-alike form that makes a certain amount of sense. The poet has in mind the darkness of the underworld; see 4.9.41 Stygias ... tenebras. But F. also prints turpia (Herwerden) for iurgia ( $\omega)$, a gross trivialization and much inferior to Ruhnken's orgia. See above on 1.4.14. H. accepts tenebris and orgia (C., pp. 136-7), G. keeps terris and introduces his own crimina.

\subsubsection{1-2}

nos uxor numquam, numquam deducet amica: semper amica mihi, semper et uxor eris.

Years ago $(A J P h$ 100, 1979, 77-8) I argued that this distich is really the beginning of a new poem, 2.7 and I did not know that Havet had proposed this already. We should also read diducet (Lachmann; see his note) for deducet (wrong prefix, as often). See now my article in A. E. Housman: Classical Scholar, edited by D. J. Butterfield and C. A. Stray (London 2009), 138-40. H. (pp. 138-40) rejects my idea and places the couplet between 2.7.5 and 7, reviving a suggestion he found in Sandbach's lecture notes. This is probably not the best of all possible solutions. G. leaves the couplet at the end of 2.6, reading subducet with Burman. Scaliger, followed by other editors, placed the couplet after 2.7.20.

\section{8 .8}

vinceris aut vincis: haec in amore rota est

In order to restore the text of 2.8.8, we first have to reconcile the information given by our sources. It seems best to begin with Smyth's Thesaurus Criticus. The reading aut vinces which already appears in the Itali is usually ascribed to Arthur Palmer. But at one time (Hermathena 9, 1983, p. 448), Palmer also wrote: "The correction at vinces is easy and, in my opinion, certain". At another time he tried aut vincis: sic (P. Ovidii Nasonis HEROIDES XIV, 1874, p. XXXVI. I am indebted to Antonio Ramírez de Verger for this clarification. On the wheel of Fortune as a symbol for the vicissitudes experienced in love cf. Tib. 1.5.69-70 at $t u$, qui potior nunc es, mea furta caveto (timeto v. 1.):/ versatur celeri fors levis orbe rotae. It seems that rota is not only the wheel itself but its movement. 


\subsubsection{3-6}

dum nos fata sinunt, oculos satiemus amore: nox tibi longa venit nec reditura dies.

atque utinam haerentis sic nos vincire catena velles, ut numquam solveret ulla dies!

To whom is velles addressed? To Cynthia, according to F. who refers to tibi, but this form is best understood as a 'dativus ethicus'. Baehrens' vellet (sc. catena) uti offers a way out, but Burman's vellent (sc. fata) is excellent, I think, and it was accepted by Kuinoel. If this is accepted, we may have to change the punctuation somewhat:

\section{dum nos fata sinunt, oculos satiemus amore (nox tibi longa venit nec reditura dies) atque utinam haerentis sic nos vincire catena vellent, ut numquam solveret ulla dies!}

The chain by which the Fates bind the two lovers together is a striking image. Lucr. 4.1109 usque adeo cupide in Veneris compagibus haeret is slightly different, because here Venus takes over the role of the binding power; see also [Tib.] 4.5.13-6 nec tu sis iniusta, Venus: vel serviat aeque/ vinctus uterque tibi, vel mea vincla leva./ sed potius valida teneamur uterque catena, / nulla queat posthac quam soluisse dies; Stat. silv. 5.1.44 is similar, and the poet seems to have this passage and 4.7.19-20 pectore mixto in mind: vos collato pectore mixtos/ iunxit inabrupta Concordia longa catena. Here Concordia (not Venus, as in Lucretius) takes the place of the deity that applies the chain. G. and H. keep velles without citing any alternatives, but, as the passages cited show, we need a higher power to bind the lovers together.

\subsubsection{7-8}

haec certe merito poterunt laudare minores: laeserunt nullos pocula nostra deos

Fontein, an outstanding textual critic, objected to pocula and proposed proelia or oscula; before him, the Itali tried lumina. But no change is necessary. Propertius almost certainly alludes to the disgrace of Cornelius Gallus, and when he speaks of 'offended gods', he must have in mind Augustus. Propertius contrasts his own way of life, dedicated to making love. In v. 47, hoc would be better than haec, as one of the referees notes. Drinking wine, writing poetry to those who, like Gallus (or Tullus, see above on 1.6.212) fought Rome's battles and contributed their share to Rome's triumphs, though Gallus also achieved fame as a poet. The allusion to Gallus was first 
recognized by David Ruhnken, it seems, but also by others, e. g., by $\mathrm{Ch}$. Merivale, History of the Roman Empire, vol. IV (1903), p. 103, as cited by Enk in his commentary on Book II, 1962, 227. D'Orville and others thought of M. Antonius. But see Ov. trist. 2.445-6 nec fuit opprobrio celebrasse Lycorida Gallo, / sed linguam nimio non tenuisse mero. Gallus acquired laus as a soldier and a love-poet, but he also managed to offend Augustus by boasting about his exploits when he was in his cups. Propertius who has no military ambitions can at least claim for himself that he never offended 'the gods', even when he had too much to drink. H. (pp. 176-7) leaves pocula in the text but prefers me (Itali, Heins., Lachm.) to haec ( $\mathrm{N}$ post corr. $\mathrm{F}^{2}$ vel Colucius Q S); G. prints nos (Baehr.) ... proelia (Fontein). But both me and nos, followed by certe, sound too assuming, I think: Propertius only demands laus in one small domain: He never offended any deity. Haec (= nec $\mathrm{N}$ primo, F P B etc.) seems necessary as a preparation of the next line.

\subsection{6 .29}

\section{aspice quid donis Eriphyla invenit amaris}

Rossberg proposed amari which was accepted by H. (p. 181) who recognized the influence of the prae-caesural noun. G. conjectured opertis for amaris, but quid ... amari seems to restore what the poet wrote. E. Hipp. 1411 (Poseidon's 'bitter gifts') could be cited to support the paradosis, but it does not seem to be a very close parallel.

\subsubsection{9-50 \\ vidisti toto sonitus percurrere caelo fulminaque aetheria desiluisse domo?}

Read probably tonitrus (Francius, cited anonymously by Broukhus.) for sonitus. Francius' conjecture can be supported by Verg. Aen. 8.391-2, cited by H. tonitru cum rupta corusco / ignea rima micans percurrit lumine nimbos. As often, a longer word got shortened in transcription. I also wonder whether percurrere would not require totum ... caelum; see, e. g., Lucr. 5.1221 cum ... magnum percurrunt murmura caelum. As far as endings are concerned, the paradosis of Propertius is often unreliable, and in this case the endings aetheria ... domo might have influenced the preceding line. Guyet (or Heinsius) proposed procurrere, while Lachmann postulated an intransitive use of percurrere. H. (pp. 183-4) accepts tonitrus, but G. feels comfortable with sonitus (cf. Ramírez de Verger, BMCR 2009-07-27, 7).

2.20.9-12

mi licet aeratis astringant brachia nodis, sint tua vel Danaes condita membra domo, 
in te ego et aeratas rumpam, mea vita, catenas, ferratam Danaes transiliamque domum

Transiliamque is a conjecture noted by $\mathrm{V}^{2}$, the hand of a humanist. The broad paradosis offers stasiliamque. What one would expect is insiliamque, and this was proposed (dub.) by Burman. F. tries to save the earlier conjecture by referring to 2.32 .59 nec minus aerato Danae circumdata muro which, according to him, must mean that Danae's house was surrounded by a wall over which one had to jump. But in fact it means that she was surrounded by walls, i. e. the walls of her domus. Even if one had jumped over that imaginary wall, one still was not with Danae, for she was inside the tower, and Propertius could not possibly say that he would jump over her tower. The $s$ - of stasiliamque probably results from dittography, and then we would only have to deal with -ta- which could very well hide in-. What transilire means in Propertius is shown by 2.18 b.38 et terram rumor transilit et maria. Guyet proposed very plausibly mi licet aerati constringant brachia nodi (wrong prefix and adjustment of endings to restore metre). G. prints $m i$ ... bracchia ...tua ... transiliamque, while H. (p. 195) accepts insiliamque but follows $\omega$ in printing me for $m i$ (Itali); he also prefers vincula (van Jever) to bracchia. Incidentally, tua in v. 10 is Santen's correction for mea (w) which editors had accepted before.

\subsection{0 .28}

possum ego naturae non meminisse tuae?

Read possim (Guyet, Heins. on Ov. epist. 8.5; met. 14.172) ego nunc curae (Suringar). NUNCCURAE became naturae, because a scribe ignored the word division, omitted one $C$ and shortened a sequence of letters, as often. H. feels comfortable with both changes (see pp. 196-7), while G. leaves possum ... naturae in the text.

\subsubsection{5-6 \\ hoc mihi perpetuo ius est, quod solus amator nec cito desisto nec temere incipio}

Housman has repaired the passage by writing haec (Itali) ... laus, and this was accepted by Goold and others. Only by a long stretch can ius in this context stand for mos, as F., following Paley, asserts. If that were the case, Propertius could have written hic ... mos, but this is not at all what he means. An abbreviated haec became hoc, but a reference suggests that haec could have become hoc from a simple palaeographical error of hec $>$ hoc. Similarly, hoc could become haec by mistake (see above) and LAVS became $I V S$ because $L$ looks like $I$, and $A$ was omitted. Cf. 2.1.47 laus in amore 
mori: laus altera, si datur uno/ posse frui. H. leaves the couplet as it is in $\omega$, but deletes it, following Jacob. Apparently, it is also missing in one or several Itali (probably because of the homoeoteleuton haec ... haec ... nec). This is not the only time that $\mathrm{H}$. removes a portion of the text in one way or another, because a simpler remedy (he mentions Housman) apparently does not appeal to him. G. leaves hoc ... ius in the text.

\subsection{2b. 44}

quid iuvat heu nullo ponere verba loco?

This is another example of the corruption of heu which here appears as et in $\omega$; it was changed to $e i$ by Haupt, and heu is due to Rothstein (see above on 1.7.16). In this case F. has accepted the conjecture, but he ignores Beroaldus' nullo pondere ... loqui which should at least be cited in the app. crit. of a modern edition. Beroaldus actually wrote in for et, following a humanist source. Pondere lost a letter, and the last word of the line was changed to make some sort of sense. Cf. 3.7.43-4 quod si .../ verba ... duxisset pondus habere mea; Ov. epist. 3.98 at mea pro nullo pondere verba cadunt. $\mathrm{H}$. (p. 205) accepts Beroaldus' emendation which he ascribes to Itali, while G. rewrites the verse as follows quid iuvat, a! nullo perdere (G.) verba lucro (G.)

\subsubsection{1-2}

quam care semel in toto nox vertitur anno! a pereant, si quos ianua clausa iuvat!

The presence of care in the hexameter should alert readers that one must read venditur (Hemsterhuys, Schrader, Emend., c. VI. p. 127). Perditur (Broukhus.) is less appealing; cf. Sen. dial. 10.16.5 noctes quas tam care mercantur, perhaps a reminiscence of this passage. It is the same theme: someone (a messenger, the door keeper, the mistress herself) has to be bribed by the lover in order to gain access or to keep an assignment; see Ov. am. 1.10.29-32 sola viro mulier spoliis exultat ademptis, / sola locat noctes, sola licenda (Y : locanda $\mathrm{P} \mathrm{S}$, recc.) venit/ et $v$ e $n$ d i t quod utrumque iuvat, quod uterque petebat, / et pretium quanti gaudeat ipsa facit. The parallel shows that the lady herself, not only her servants, expected gifts or cash; hence, in Propertius, we might consider quas (Itali) for quos in v. 12. Propertius and Ovid are not speaking of prostitutes but of ladies of the upper classes. $\mathrm{H}$. introduces his own conjecture venerit which is no improvement. His objections against venditur are found in C., pp. 208-9. He accepts quas in v. 12. G., too, prefers a conjecture of his own, ducitur, to venditur and leaves quos. 


\subsubsection{9-50 \\ iam deus amplexu votum persolvit; at illi aurea divinas urna profudit aquas}

The myth itself and the context which it illustrates suggest nam (Vahlen)...amplexae (Postgate) ...et (J K W) for iam ... amplexu ... at. That iam here means statim is one of F.'s improbable assertions. Amplexae is better than amplexus (Passerat), because it provides an indirect object to persolvit and avoids the homoeoteleuton deus amplexus. It also anticipates illi and confirms et, I think. Amymone allowed herself to be seduced by Poseidon, because he promised her something, and he kept his promise; that is why she pours divine waters out of a golden urn, testifying that gods can be kind and fair to mortal women. A logical sequence connects the god's promise, Amymone's willingness and her reward; hence et instead of at. $\mathrm{H}$. (p. 227) gives us nam ... amplexae ... at, while G. prints iam ... amplexu ... at. Incidentally, Vahlen's nam for iam is a good illustration of Kenney's First Law $(C Q 8,1958,65)$ that "any monosyllable at the start of the verse may have arisen from any other” (see H., C., p. 410).

\subsubsection{5-6}

sed tibi vexatae per multa pericula vitae extrema veniet mollior hora die

It seems to me that post (Pricaeus on Apul. met. 11. P. 666, Markland) would make more sense than per, since the poet is really thinking of her last day of life when all crises are behind her. Per would be better with vexata ... vita (Itali). Furthermore, veniat (Itali) may be better than veniet which is itself a conjecture $\left(\mathrm{V}^{2}\right)$ for the impossible venit $(\omega)$. The paradosis lost a letter, and the optative veniat is, perhaps, more suitable than the straightforward prediction veniet. Finally, aura (Passerat ex codd., Pricaeus) should replace hora. Once more, the passages assembled by F. prove nothing, for in Ov. epist. 3.44 and Pont. 3.3.84 most editors now prefer aura: see also trist. 4.5.20 (and my note, 1977). Read probably

\section{sed tibi vexatae post multa pericula vitae extrema veniat mollior aura die.}

G. keeps per, changes vexatae to versatae, prints aura and considers veniat his own conjecture. H. (p. 233) edits per ... veniat ... hora. H. notes that pericula vitae is a standard phrase which allows vexatae to be read with tibi and per to be retained. 
$2.29 .15-8$

quae cum Sidoniae nocturna ligamina mitrae solverit atque oculos moverit illa gravis, afflabunt tibi non Arabum de gramine odores, sed quos ipse suis fecit Amor manibus

Read Sidonias, nocturna ligamina, mitras. The garment Cynthia wears at night is not a mitra which, in the singular, designates an 'oriental headdress fastened under the chin' (OLD s.v., referring to Prop. 4.2.31 cinge caput mitra). Only the plural, mitrae, describes the two cups of her brassiere which had, indeed, ribbons attached to them and may have vaguely looked like a pair of headdresses connected with each other. The function of Cynthia's garment has often been misunderstood, e. g. by G., in his translation. It was not a night cap. Propertius almost certainly had in mind an epigram by Hedylus (II Gow and Page, Hellenistic Epigrams, Cambridge $1965=$ AP 5.195.5):

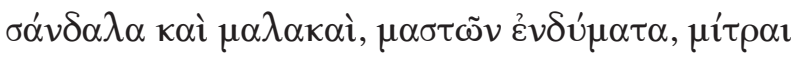

These articles had belonged to Aglaonike and are still redolent of her perfume (vv. 3-4; cf. Prop. vv. 17-8). After a symposion and a night with her lover, Aglaonike dedicated her sandals and her strophion (see Gow and Page, pp. 177; 578) to Aphrodite. This poem from Meleager's Garland, a collection which Propertius knew (see A. Hollis, in Brill's Companion, 107-8) also uses the type of apposition which is familiar from Verg. ecl. 1.57 raucae, tua cura, palumbes. Otto Skutsch called it schema Cornelianum because he thought that Gallus had introduced it into Roman poetry (see my note on Ov. met. 4.669 in Exemplaria Classica 12, 2008, 50-1, n. 3). Clearly, Gallus could have found it in Hellenistic poetry, and the similarities pointed out make Propertius' direct knowledge of Hedylus almost certain. In the paradosis of Propertius, this type of apposition was not always recognized, it seems, and the plural was changed to singular; see below on 4.7.63-4 and the conclusions.

\section{$2.32 .15-6$}

The poet describes (11-6) some of the splendid new attractions of Rome. One of them is the fountain of Triton. The transmitted text is unsatisfactory in several ways. F. has removed the most obvious error, but two more remain in his text:

et leviter toto (tota $\omega)$ nymphis crepitantibus orbe (urbe $\omega$ ) cum subito Triton ore recondit aquam 
Heinsius proposed toto ... orbe, but he also proposed refundit for the unusual recondit. The mechanism of the fountain seems to work like this: every now and then Triton refills the basin with water flowing from the concha he is holding to his mouth, and this produces the gentle crackling sound the poet describes; see Verg. Aen. 11.299 fremunt ripae crepitantibus undis. The water which fills the basin is, of course, identical to the liquid mentioned in the hexameter, and it is difficult to understand why F. insists on printing nymphis which evokes the wrong associations. Former commentators thought of statues surrounding the basin (see Lachmann's note). The word was corrected to lymphis in the Itali, and F.'s references to 3.16.4; 22.26 are not helpful; he himself prints forms of lympha in 1.2.12; 11.12; 3.3.51; 3.10.13; 4.6.7; 9.35; 59. G. prints toto nymphis ... orbe/ cum ... refundit (Heins.), while H. keeps tota nymphis ... urbe; he also accepts Heinsius' refundit but changes the beginning of the hexameter to et sonitus.

\subsubsection{9-20}

ipse meas solus, quod nil est, aemulor umbras, stultus, quod stulto saepe timore tremo.

For the second quod which is probably repeated after the first, as F. observes, we find qui in the Itali (quid D V), and for stulto Heyworth now offers falso which must be right. Thus we have two "errors of perseveration" in one couplet. Read:

$$
\text { stultus qui falso saepe timore tremo. }
$$

H. also adopts Heinsius' meae ... umbrae (proposed doubtfully Adversaria, p. 714) which has been neglected by recent editors; aemulor, I am jealous of', requires the dative; cf. Cic. Tusc. 1.44. G. keeps meas ... umbras and prints Heinsius' stultus et in nullo.

\subsection{3-6}

Orphea detinuisse feras et concita dicunt flumina Threicia sustinuisse lyra; saxa Cithaeronis Thebas agitata per artem sponte sua in muri membra coisse ferunt.

Two famous examples for the power of music. In v. 3 read perhaps delinisse (Ayrmann, in: Sylva Emendationum Criticarum, p. 7); cf. Hor. ars 393 (Orpheus) dictus ... lenire tigris rabidosque leones; Quint. inst. 5.8.1 Sirenum cantu deleniti; Apul. flor. 17 ille immanium bestiarum delenitor. The word may have been corrupted by the anticipation of sustinuisse. If Mart. 14.166.2 is sound, the corruption could be very old. In v. 15 per artem seems too vague; we need an epithet. Thebas (probably a gloss) is unconvinc- 
ingly defended by F.; read Phoebeam (Jortin); cf. Stat. silv. 3.2 .41 nec cano degeneri Phoebeum Amphiona plectro. In Propertius, Threicia lyra and Phoebea ars would balance each other. G. keeps detinuisse and Thebas but changes the innocuous agitata to advecta. H. (pp. 286-7) also keeps detinuisse (cf. Hor. carm. 1.33.14; H.'s parallels are not of equal value), and he prefers Thebanam (Heins.) to Phoebeam.

\title{
$3.2 .7-8$
}

quin etiam, Polypheme, fera Galatea sub Aetna ad tua rorantis carmina flexit equos

Read ferox (Wakker who also changed equos to aquas). It is the same case as 1.5.12: the epithet was assimilated to the last word of the line. 'Wild Aetna' is irrelevant: the point is that even wild Polyphemus was able to charm beautiful Galatea with his songs. Butrica $(C Q 47,1997,148)$ also found ferox attractive. Cf. Cic. Tusc. 5.115 Polyphemum cum Homerus immanem ferumque finxisset (not the same story, but the same type of uncouth character and presumably the same locale). H.'s objections (p. 288) are not compelling; for epithets following vocative names cf. 2.33b.29; 3.3.30 Pan Tegeaee; 4.11.38. G. also leaves fera in the text.

\subsubsection{1-2}

ille potest nullo miseram me linquere facto et qualem nolo dicere habere domi

This couplet illustrates both the sad state of the paradosis and the remarkable ingenium of Arthur Palmer. $\mathrm{N}$ comes closest to the truth with et qualem (also found by Broukhus.) nullo (influenced by nullo immediately above), but the broad paradosis has (a)equalem nulla, and Palmer found nolo hidden in nullo. G. prints Palmer's corrections but reads domo ( $\omega$ ) for domi (Heins. ex Italis). I suspect that an original domi was assimilated to the corrupt form nulla and thus became domo. H. follows Palmer and Heinsius. To witness how the great critics of past ages struggle with a problem whose solution was found later - knowing the solution - is always an experience.

\subsubsection{7-30}

\author{
illum turgentis ranae portenta rubetae \\ et lecta exsuctis anguibus ossa trahunt \\ et strigis inventae per busta iacentia plumae \\ cinctaque funesto lanea vitta toro
}

Ranae ... rubetae is a tautology, because a rubeta actually is a kind of frog. Heinsius (Castigationes in Vell. Paterc. 2.7) saw that sanie is hiding in 
ranae, and this is what the poet probably wrote (see R. Tarrant, in Günther's Companion to Prop., 52). The corruption may have been caused by a gloss. In the pentameter exsertis unguibus (Mitscherlich on Hor. epod. 5.20 after Broukhus.) is very attractive. In v. 29 read recentia (Francius, Heins.) for the meaningless iacentia. In magic it was important that the places of cremation and burial where bones and other requisites could be found had been used recently. The tabellae defixionum were regularly buried in or near a fresh tomb. Tinctaque (Barber) for cinctaque ( $\omega)$ should not be ignored: visual evidence that the vitta had actually served in a burial would make it more potent. The color is indicated by Ov. Ib. 233-4 membraque vinxerunt tinctis ferrugine pannis / a male deserto quos rapuere rogo. H. (pp. 3067) accepts sanie and prints exsucis (Burman) anguibus as well as recentia, but he prefers his own conjecture, rapta, to tincta. I wonder how bones could be collected from or by 'dried up snakes'. Witches worked with human bones, and exsertis unguibus describes exactly the fingers of those collecting them; cf. Stat. Theb. 2.513 acuens exsertos protinus unguis (of the Sphinx). G. keeps ranae and picks ex sectis (P, Otto) anguibus.

\section{7}

Our understanding of this elegy has been greatly advanced by the discussion of some fragments from a Hellenistic poem by E. Livrea in ZPE 139, 2002, 37ff; cf. also G. O. Hutchinson, ibid. 138, 2002, p. 6. This poem, probably Euphorion's Philoctetes, which almost certainly served as a model to Propertius, seems to confirm, among other things, Muretus' transposition of vv. 21-4 between 38 and 39, accepted dubitanter by F., following Housman (see Heyworth, in Housman, etc., p. 18) and Butler \& Barber (1933, p. 277).

Furthermore, the Greek fragments show that, in v. 60,

\section{attulimus longas in freta vestra manus}

we are not dealing with an 'error Wattianus' (W. S. Watt, in CQ 54, 2004, 659-60). There is no need to change longas to castas or puras (Francius) or vacuas (Giardina), nor should we change manus to comas (Oudendorp, van Eldik accepted by Watt). What Propertius wrote is longas ... manus (printed by F., dubitanter), and this is entirely consistent with the poet's emphasis on Paetus' greed.

One more point, not directly affected by the discovery of the papyrus. In vv. $47-8$

non tulit haec Paetus, stridorem audire procellae et duro teneras laedere fune manus

I once liked noluit (O. Skutsch), but now I think we should write praetulit haec Paetus: stridorem ... Paetus actually chose to expose himself to all 
the hardships of a sea voyage in order to get rich, instead of staying at home, leading a simple life. The prefix of the first word of the line was not recognized. Haec points ahead, as in 1.20.1 (cf. has in 1.16.13, see above). Then we should also read et for sed in v. 49, an easy change. H. (pp. 310-1) deletes 21-4 and places the lines at the end of the poem. In v. 60 he follows Oudendorp and Watt. In v. 43 he reads (pp. 313-4) nunc tulit et (Barber and H.). G. also deletes vv. 21-4, following the Eton edition and reads vacuas ... manus (v. 60 ) and non tulit haec (v. 43). G. and H. do not seem to be aware of Livrea's important contribution. On the connections between Euphorion, Cornelius Gallus and Propertius see the excellent observations of A. Hollis in: Brill's Companion, pp. 97-101; Hollis deals briefly with 3.7.21-2 but concentrates on a similar poem, 2, 26A, which, to him, illustrates the 'color' of Euphorion. I find this very convincing.

\subsection{7-8}

et Tyros ostrinos praebet Cadmea colores cinnamon et multi pastor odoris Arabs.

Propertius condemns the luxuria, the expensive life style of Roman ladies which requires costly dies and perfumes from the Near East. Pastor is hardly possible for someone who cultivates and sells plants, herbs and spices. Pistor (Bury, Shackleton Bailey), the one who grinds or mills them, is very close to the 'ductus litterarum', but the word is normally used for domestic millers and bakers, not for oriental exporters of luxury goods. According to F., Fontein proposed multi cultor, Lachmann suggested culti messor; the first conjecture can be supported by [Tib.] 3.8.18 cultor odoratae dives Arabs segetis, the second by Mart. 3.65.5-6 quod myrtus, quod messor Arabs, quod sucina trita, / pallidus Eoo ture quod ignis olet and perhaps also by Sen. Herc. f. 909 quicquid Indorum seges/ Arabesque odoris quicquid arboribus legunt, / conferte in aras where one may consider Indo fert seges (Koetschau). See Stat. silv. 3.3.33 messes Cilicumque Arabumque superbas. We should not forget Heinsius' multi coston odoris Arabs which neatly balances cinnamon. G. replaces pastor by Rossberg's praestat, and H. (pp. 347-8) prefers culti messor.

\section{$3.13 .15-22$}

Propertius admires the Indian widows who consider it a privilege to die on their husband's funeral pyre. In v. 21 ardent victrices et flammae pectora praebent, the first word must be corrupt. What the poet wrote is surely gaudent (H. Stephanus, Schediasm. V 10, followed by Passerat, Broukhus. and others). The first letter was lost, and audent was read as ardent, perhaps under the influence of flammae. It is quite clear that, for the widow who 
won the competition (it is described as such), this was a kind of triumph. Following W. Heckel, J. C. Yardley and J. Butrica, H. (p. 349) cites the testimonies from Cicero, Diodorus and Valerius Maximus which confirm gaudent; they all stress the joy of the widow who is allowed to die. G. prints his own plaudunt (meaning that they applaud themselves as they burn on the pyre?), but H. (C., p. 349) recognizes the value of gaudent.

\subsubsection{3-4}

qualis Amazonum nudatis bellica mammis

Thermodontiacis turba lavatur aquis

It is difficult to understand how F. could still print turba without even mentioning turma (Gulielmius, Quaest. Plaut., 240, Heinsius ex cod., Ramírez de Verger, 1989, 66), the obvious noun to go with bellica; see 2,10, 3 fortis ... ad proelia turmas; Ov. Pont. 4.2 .51 et tu, femineae Thermodon cognite turmae where the MSS. vary between turmae (B C), turb(a)e and turbis. Ovid probably had in mind this passage in Propertius. G. leaves turba in the text and transposes 15-6 after 19, following Palmer. H. (p. 360) prints turma ... vagatur agris (Heins.). Cf. Stat. silv. 1.6.53 Thermodontiacas ... turmas.

\subsubsection{3-4}

quod si iura fores pugnasque imitata Laconum carior hoc esses tu mihi, Roma, bono.

Pugnasque is odd, for the poem deals mainly with the athletic training of the Spartan women, not with real battles. Pugnosque (Otto) would fit the general theme and is very close to the 'ductus litterarum', but we would have to take it as a reference to boxing. Moresque (Shackleton Bailey) and legesque (Butrica) would go well with iura. But luctasque (Fontein) seems superior to me, because the last couplet repeats essentially the first one: multa tuae, Sparte, miramur iura palaestrae, / sed mage virginei tot bona gymnasii. Here, iura corresponds to iura, tot ... bona corresponds to hoc ... bono, and what would best correspond to palaestra, the wrestling-place, appears to be lucta, the wrestling-match. H. keeps pugnasque, G. prefers legesque.

\subsubsection{0, 45-6, 43-4, $11 \mathrm{ff}$.}

This sequence of lines was proposed by Fischer, and I think he was right. It lends more credibility to a conjecture made in v. 11

testis erit Dirce tam vero (vano Franz) crimine saeva. 
There are, of course, vera and falsa crimina, but Antiope, it seems to me, is punished by Dirce harshly for something she never did. This is the whole point, and the change seems necessary, no matter what order of lines we adopt. Cf. Ov. met. 7.829 crimine concita vano. $\mathrm{H}$. (p. 365) adopts a different order: $3-4,5-10,45-6,1-2,43-4$, 11ff. He also leaves vero in the text and defends it (pp. 365; 367-8), but I think he misunderstands the connection between Lycinna whom the poet calls non meritam (v. 43) and Antiope who, in his view, is also innocent. Otherwise she could not expect Jupiter to come to her aid (19-22), as he does (35-42). The gods are often fair to the mortal women they seduce (see above on 2.26.45-50). The poem loses its whole pathos if Antiope is guilty. G. solves the problem in his own manner, by writing non vero, at least doing justice to the context; he also changes saeva to questa.

\subsubsection{9-40}

Antiope, cognosce Iovem: tibi gloria Dirce ducitur in multis mortem habitura locis

Most editors seem to have accepted mortem habitura, even though mortem obitura (Heins.) would restore the proper idiom. Mortem (h)abitura and mortem obitura look very much alike, but the latter is probably what the poet wrote. A similar corruption is found in Ov. met. 9.98-9 hunc tamen ablati doluit iactura decoris, / cetera sospes habet, where it is said of Achelous that in his fight with Hercules he lost his beautiful horn but was otherwise unhurt; here we need tantum (Paris. Lat. 8001, Markland) ... abit (Heins. ex cod.); see Exempl. Class. 12, 2008, 57. In Prop. 3.15, both G. and H. adopt Heinsius' correction, but H.'s punctuation tibi gloria; Dirce..., 'yours is the glory; Dirce ...' (p. 579) is somehow affected, I feel; should we not take tibi gloria as an apposition?

\subsubsection{3-4}

vesanumque nova nequiquam in vite Lycurgum Pentheos in triplices funera grata greges

Heyworth's (pp. 378-9) admirable et triplici ... gregi makes all other attempts unnecessary. We need $e t$ which became in (loss of $-t$ before $t-, e$ taken for $i$ ), and the endings were adjusted accordingly). H. explains the corruption differently: An $s$ which looked like an $f$ was added to triplici from the following funera. G. prints in triplices f. carpta g. (Heins.).

\section{$3.17 .29-38$}

Throughout this whole poem, Propertius speaks of himself, and we need the first person singular in some places where the paradosis has substituted 
other forms. Read onerabo (Itali, Passserat) for onerato in v. 29 and libabo, I think, (not libabit with Foster) for libatum in v. 38. In the paradosis the sequence of endings in -abo was misunderstood, it seems; other future endings were preserved. He now wishes to be a vates, priest and poet (cf. 4.6.110 ), in the service of Bacchus, and in exchange for his devotion, Bacchus will deliver him from a servitium that has become more and more difficult to bear (41-2) and cure him by his blessings (3-4). Bacchus once joined him to Cynthia, but he can also separate him from her (5). The whole poem is an announcement of the now inevitable separation from Cynthia, presented in the form of a hymn to Bacchus.

At the same time, it is a kind of preview of a more formal hymn to Bacchus in the style of Pindar. When Propertius says "I will burden your neck with a garland ...", he means "I will say that your neck is burdened by a garland ...' This is Pindar's manner, as H. (p. 379), following Cairns, has now established. This is the key to the understanding of this elegy. H. (p. 379) prints onerabo and accepts libabit (Foster), but who else could be this priest but Propertius himself? G. reads onerato (29) and libabit (38).

\subsubsection{1-2}

tuque o Minoa venumdata, Scylla, figura, tondes purpurea regna paterna coma

F. accepts tondes (Y C, Dawes, Keil) for tondens, but cites Markland's purpuream ... comam only in his app. crit. Here, as in 2.19 .15 (see above) and elsewhere, an apposition was misunderstood, and we have to restore the original endings. The purple lock on her father's head is the royal power he has, and when Scylla cuts it off, he has lost his kingdom. The direct object of her action can only be the lock, but that lock represents his whole power as king. Read: tondes purpuream, regna paterna, comam. G. prints tondes ... purpurea ... coma, while H. (C., pp. 389-90), following Burman, keeps tondens but accepts Markland's proposal, marking the apposition. Read also J. P. Postgate, "Propertiana", CPh 8, 1913, 330-1, who supported this combination of proposals.

\section{$3.20 .5-6$}

at tu, stulta, deos, tu fingis inania verba: forsitan ille alio pectus amore terat.

Rossberg's stulta adeo's is very attractive. The gods really have nothing to do with this. The error can be explained by wrong word division, but we have a similar case in 3.16.14. See Butrica, in: $C Q 47,1997,181-2$ where the true reading, nemo adeo ut feriat barbarus esse volet, has only survived in the indirect tradition; all our MSS. have nemo deo ut noceat b. e. v. which 
shows once more what strange things can happen in this paradosis. Nemo deo was probably the first step in the process of corruption, and then, since no one can 'hit' a god, feriat was changed to noceat. See also above on 1.4.26, below on 4.6.59-60. H. (pp. 392-3) leaves deos in the text but suggests in the app. crit. testaris for tu fingis. G. modifies Rossberg's idea to adeo, but we need the es which survives in deos.

\subsubsection{5-7}

ergo, qui pactas in foedera ruperit aras, pollueritque novo sacra marita toro, illi sint quicumque solent in amore dolores

In this poem which is not addressed to Cynthia but to a new, unnamed love everything indicates that the poet is now considering a serious relationship, akin to a marriage. The couple observes the omina (24), they sign a written agreement and seal it (15-8) and they apparently perform a kind of ritual in front of the domestic altar to make sure that the gods bless their union. It would make sense to read either ergo qui tactis haec foedera ruperit aris (Burman, van Eldik) or ergo qui tacta sic foedera ruperit ara (Housman). The plural is, perhaps, better, because to be on the safe side, two altars (his and hers) should be touched, and sic seems inferior to haec in this context. Surely there can be no question of breaking the altar or the altars. Lachmann was puzzled by this 'mirus loquendi modus', and then found a slippery way around it. But only the foedus can be broken; foedera must be the object of ruperit, and in is corrupt. Tactas for pactas is already found in the Itali, and it is confirmed by Verg. Aen.12.200-1 audiat haec genitor qui foedera fulmine sancit. / tango aras, medios ignis et numina testor: / nulla dies ... foedera rumpet. See C. O. Brink, in RhM 115, 1972, 31-2. G. has tactis haec ... aris, H. tacta ... sic ara.

\subsubsection{7-8}

persequar et studium linguae, Demosthenis arma, librorumque tuos, docte Menandre, sales

The poet is planning a trip to Athens, not just as a tourist, but to follow lectures in Plato's Academy and Epicurus' Garden, it seems, to study Greek rhetoric and to enjoy the wit of Menander's plays. Librorumque is perplexing. Would he have to read Menander's plays in a library or a bookstore in Athens instead of seeing them performed on the stage? Moreover, persequar ...arma ... et sales is a strange type of zeugma. We need another verb along with persequar, also with a future ending, and Suringar supplied it with libaboque (see Butler \& Barber, Comm., 315;). Libo 'to nibble at' can have as its object food as well as literature; hence it is particularly appropriate to the 
two meanings of sales. Cf. Rhet. Her. 4.3.5 libandus est etiam ex omni genere urbanitatis facetiarum quidam lepos. The epithet docte can be supported by Manil. 5, 475, but coming after docte Epicure two lines before, it is probably a mechanical repetition. The conservative editors like F. miss the main point: it is possible to accept docte Epicure as well as docte Menandre in separate contexts, but a poet like Propertius would never have used the same epithet for two different authors twice within three lines. Read, perhaps, culte Menandre with Heinsius. G. prints his conjecture urbanosque ... culte (Heinsius, Dorville), while H. accepts libaboque and prefers munde (Kuinoel). Dorville also suggested compte, a quality attributed to Isocrates by Quint. Inst. 10.1.79 and to Ovid by the Elder Seneca, contr. 2.2.8.

\subsubsection{5-6 \\ Albanus lacus et socia Nemorensis ab unda, potaque Pollucis nympha salubris equo}

The paradosis offers socii, sotii and sotiis which was changed to socia by Puccius, after a MS, it seems, to go with unda. But Housman recognized in $A B V N D A$ the form $A B V N D A N S$ which had lost two letters at the end of line. The next step was to restore FOLIIS from SOTIIS which Housman did. This is surely one of his most beautiful emendations. (On this type of corruption see my note in $M H$ 66, 2009, 88-9). Here one should quote Christoph Martin Wieland, the German poet and translator who said: "Eine Conjectur von Hemsterhuys, Bentley, Wolf kann mich unendlich glücklich machen. Die irren sehr stark, die glauben, dass solche Männer blosse Büchermotten gewesen wären. Sie hatten Genie zu allem, was sie anfingen. Sie hätten eben so gut grosse Dichter, als grosse Critiker werden können." (I owe this citation to Arnd Kerkhecker). Housman himself is the perfect illustration. Maybe no one would rank him as a 'great poet' today, but his success and his fame as a literary craftsman are undeniable. F. mentions Housman in his app. crit. as one solution among others but sees no need to change his text. G. seems happy with socia ... ab unda, but H. (p. 405) gives Housman's emendation the place it deserves. Nympha does not make much sense; the reading has been changed here and in related passages to lympha long ago.

\subsubsection{7-8}

nil patrium nisi nomen habet Romanus alumnus: sanguinis altricem non pudet esse lupam

It is not clear from F.'s apparatus that the reading non pudet is only found in P. It seems to be an error in transcription or a bad conjecture for non putet (N F L alii). A Roman should not be ashamed to descend from a she-wolf, but looking at others he might wonder whether this is not just a 
myth. But if putet is right, non becomes doubtful. Volscus proposed nunc pudet, Burman num pudet, and num would work very well with putet, making v. 38 a question: 'Would he believe that a she-wolf nurtured the blood from which he sprang?' Someone no doubt has suggested this before. G. has non pudet, while $\mathrm{H}$. opts for non ( $\omega)$ putat $(\mathrm{R})$ and mentions Hutchinson's quis for non.

\subsubsection{5-6}

tunc animi venere Deci Brutique secures, vexit et ipsa sui Caesaris arma Venus.

Read probably hinc (Heins.) ... rexit (Heins.) or auxit (L. Mueller). The first word of the line was probably difficult to read. Rexit (very close to the paradosis) could be supported by Stat. Theb. 7.251 video quae noster signa Menoeceus, / quae noster regat arma Creon, while auxit has parallels in Ov. met. 14.454 auget uterque suas externo robore vires; Tac. hist. 2.32.2 tum auctis viribus certaturos. In both lines in the paradosis of Propertius the first word was difficult to read. There has to be a connection between the historical significance of Aeneas' escape from Troy (39-44) and the heroes of Roman history. Tunc just indicates a vague chronological sequence. Vexit introduces a myth that is not attested anywhere, as far as I know. One cannot defend the paradosis by comparing Ov. met. 15.844-5 and Petron. 124.266-7, as F., following Waszink, attempts. Ovid refers to Venus' intervention after the assassination of Julius Caesar, carrying his soul up to the heavenly sphere (no weapons mentioned), and Petronius' vision of Venus leading Caesar's army is different again: Dione/ Caesaris arma sui ducit; here the verb is ducit, not vexit, and arma means 'army', not 'arms'. In Propertius, the context is different: The great deeds of the Roman national heroes (Decius, Brutus, Caesar) are derived from Aeneas' devotion to the Trojan Penates and to his own father, Anchises, who had been beloved by Venus. Heinsius considered also hinc magni venere Deci which is excellent and duxit for vexit, actually referring to the passage from Petronius quoted above. G. prints hinc animi venere Deci and vexit, while H. (p. 420 leaves tunc and prefers venit (Hollis) to other conjectures. See also F. G. Welcker, Die Griechischen Tragoedien, Bonn, 1841, I, 1391.

\subsection{9-10 \\ at postquam ille suis tantum concessit alumnis, Vertumnus verso dicor ab amne deus}

'but after he (the Tiber) granted so much to his foster-children...' How much? Tantum is too vague and probably hides spatium (Heins.) or stagnum (Housman), through loss of $s$-after -s. Campum (Itali, Heins.) is also 
plausible; it has been explained as Campus Martius and would have to be capitalized. H. (C. p. 437) prints stagnum, G. mentions campum and spatium but in the end keeps tantum. Write probably spatium (Heins.). Tractum was suggested by D. J. Butterfield (Eikasmos 20, 2009, 198, n. 17).

\subsubsection{1}

haecne marita fides et +parce avia+ noctes

This is the text of N. To the many proposals listed by the more recent editors I would like to add the very attractive conjecture offered by Antonio Ramírez de Verger in his review of Heyworth's OCT and Cynthia (in BMCR 2009):

haecne marita fides et pactae gaudia noctis

This is very close to $\mathrm{N}$ and gives exactly the meaning we would expect. Pactae ... noctis stands for primae noctis matrimonii quod pacta sum, and among the parallels listed by Ramírez de Verger, Ov. ars 3.461-2 is particularly striking: si bene promittent, totidem promittite verbis:/ si dederint, et vos gaudia pacta date. Here, gaudia pacta corresponds perfectly to pactae gaudia noctis. H. (p. 446) prints pacta haec foedera nobis (Watt) where nobis seems redundant. G.'s opacae gaudia noctis, 'le gioie di quella notte oscura', borders on the whimsical.

\subsubsection{3-4}

omnia surda tacent, rarisque assueta kalendis vix aperit clausos una puella Lares.

Read probably limina (Heins. dub.) and ad sueta (Palmer). Omnia is possible, but limina is more concrete, less vague. Heinsius refers to 1, 16, 18; 26. Adsueta can only be taken with raris ... kalendis which makes very little sense, whereas ad sueta, 'to perform the customary rites' is supported, e. g., by Varro, rust. 1.1.7 deis ad venerationem advocatis; Apul. met. 4.24 se ... ad sectae sueta conferunt. A case of wrong word division. H. takes raris as 'widely-spaced'. Clausi Lares must mean the front-door of the house as in 4.8.49-50 cum subito rauci sonuerunt cardine postes / et levia ad primos murmura facta Lares. G. leaves omnia ... adsueta in the text, H. adopts limina, but keeps assueta.

\subsection{1-2}

Tarpeium nemus et Tarpeiae turpe sepulcrum fabor et antiqui limina capta Iovis 
Here, nemus ought to be scelus (Kraffert: see Camps, 1965, ad loc.), and if we accept that, we should probably also consider Tarpeiae for Tarpeium. Neither Propertius nor (as far as I know) anyone else mentions a 'Tarpeian Grove'; Verg. Aen. 8.347-8, cited by F., proves nothing at all. Throughout the poem, Propertius presents what Tarpeia did as a shameful crime for which she deserved to die (17-8; 43 crimen: 56 prodita Roma; 69 culpam; 85-7; 89 sceleri; 93-4). H. leaves Tarpeium nemus in the text, G. reads Tarpeium montem which seems quite improbable. In my opinion, TARPEI(A)ESCELVS could easily become TARPEIVMNEMVS.

\section{$4.4 .75-8$}

annua pastorum convivia, lusus in urbe, cum pagana madent fercula divitiis, cumque super raros faeni flammantis acervos traiicit immundos ebria turba pedes.

Propertius was a careful observer of Roman folklore, but the paradosis distorts the valuable information he passes on. For divitiis read lautitiis (Postgate), and for raros read perhaps ternos (Butrica). Deliciis (Beroaldus ex codd.) is also possible, and for sacros (Passerat) see below. Immundos ... pedes is a humanist conjecture, found, e. g., in the liber Colotii, and accepted by Passerat, Guyet and Heinsius. All major MSS. have immundas ... dapes. In v. 75 one should consider herba (Fontein) for urbe. This may have been written (h)erba which, at the end of the line, could easily become urbe. G. keeps urbe and raros but prints Postgate's lautitiis, H. (p. 452) also keeps urbe; he does not change divitiis, but for raros he adopts sacros (Passerat) which is very good; the original reading may have been corrupted because the $-r$ of super was written twice. Cf. Tib. 2.5.90 flammas transiliet ... sacras; [Tib.] 3.12.21 sanctos ... turis acervos.

\subsubsection{3-4}

a duce Tarpeia mons est cognomen adeptus:

o vigil, iniustae praemia sortis habes

Read probably Tarpeium (Palmer) ... iniuste (F L P alii, Lachmann dub.) praemia mortis (Lachmann, Lütjohann) habes. The sense is clear: Mons Tarpeius has its name after Tarpeia who led the enemy to its top. Tarpeio $(\omega)$ could be TARPEIOM after having lost its $-M$ before MONS by haplography. Tarpeia is a humanist conjecture, but not a very good one. Tarpeia's fate was not at all unfair; she deserved to die, but it is unfair that she was rewarded by giving her name to a prominent Roman hill. The ThLL 7.1.1689.60 explains iniuste correctly, I think, as immerito. There is a problem with o vigil; something was lost at the beginning of the line, but non 
vigil (Peerlkamp) or o virgo (Guyet) can hardly be the solution. H. (453-4) prints a duce turpe Iovis (Weidgen) ... iniustae ... sortis, while G. resorts to a conjecture of his own and an older one: infaustae (G.) ..noctis (Itali apud L. Latinium). A referee asks "What is really so wrong with o virgo iustae...?" Nothing that I can think of right now.

\subsection{7-8}

\section{Penelopen quoque neglecto rumore mariti nubere lascivo cogeret Antinoo}

Guyet's quae 'the sort of person who...' should not be forgotten; the whole period flows more easily when we substitute it for quoque which may be interpolated, as more than once in the paradosis of Ovid's met. $\mathrm{H}$. accepts quae, G. keeps quoque.

\subsection{3-4 \\ cera Philiteis certet Romana corymbis et Cyrenaeas urna ministret aquas}

Propertius is competing with Philetas and Callimachus, and for this imaginary poetic agon he puts on a wreath in the Roman manner, just as the Greek poets would wear one in the Greek style. Cera cannot be right; we must read serta (Scal.) to balance corymbis. The first word of the line was misread and lost a letter in transcription. Certent (Scal.) is not absolutely necessary, for Propertius (2.33.37) uses serta like a fem. sg., as noted by Charisius and another grammarian. Here, as elsewhere, the indirect tradition seems to be reliable. H. (p. 457) accepts serta and keeps certet, while G. changes cera to ara (Haupt) and certet to niteat (G.), losing the idea of a poetic competition. Incidentally, if we read Cyrenaeis, should we not also read Philitaeis, as proposed by Volscus?

\subsection{7-8 \\ spargite me lymphis, carmenque recentibus aris tibia Mygdoniis libet eburna cadis}

Modis is cited from Itali by H., and it was conjectured by Scaliger, but he does not put it into the text, even though cadis is extremely odd. One can understand a flute, playing in a certain style, offering a sacrifice of song at an altar, but how can a musical instrument draw its tunes from a vessel? Can one say that these large Phrygian jars full of wine correspond in some way to the pitcher providing water from Cyrene (v. 4)? The change from cadis to modis is very easy, especially at the end of the line. Heinsius cites the reading from a 'vetus codex' and from Beroaldus, while G. who accepts 
it, ascribes it to Beroaldus and Pocchus. Scaliger actually printed Cadis with a capital $C$ and was followed by Broukhusius and Lachmann, but what is gained by this?

\subsubsection{7-8}

Actia Iuleae pelagus monumenta carinae, nautarum votis non operosa via

Editors have been printing this for centuries, probably without fully understanding it, but no real improvements were available. Now they are, thanks to Heyworth (pp. 458-60):

\section{Actia Iuleae celebrant monumenta carinae, nautarum votis nunc onerata via est}

H. brilliantly changed pelagus to celebrant and operosa to onerata, while nunc for non is due to Carutti, and est survives in P. Obviously, the couplet suffered major corruption, and major efforts were needed to restore it, but now it makes very good sense. We now can envision an imposing monument celebrating Augustus' victory at Actium, and a road leading up to it, flanked by the more modest votive offerings of the sailors who survived the battle. G. accepts the vulgate.

\section{$4.6 .27-8$}

cum Phoebus linquens stantem se vindice Delon

(nam tulit iratos mobilis un[d]a Notos)

Neither unda ( $\omega)$ nor una (Itali) really works: what we need is ante (Lipsius; see Broukhus. ad loc.) which gives us the contrast to stantem. Delos once was a floating island, but after it had offered an asylum to Leto, his mother, Apollo became its protector and made it stable. See Ov. met. 6.333-4 quam (sc. Latonam) vix erratica Delos / orantem accepit, tum cum levis insula nabat. H., following Lachmann, accepts ante, G. is satisfied with una.

\subsubsection{9-60}

at pater Idalio miratur Caesar ab astro:

'tu deus: est nostri sanguinis ista fides'

Here, F. printed one of his own conjectures: tu deus: est, adapting Richter's equally misguided tu deus es. The MSS. are divided between sum deus est (N F L P V), sum deus et (D Vo V $\left.{ }^{2}\right)$ and sum deus en (Itali). But Caesar who became a god after his death cannot say to his adopted son who is still 
alive 'I am a god, because you have just won this battle'; nor can he say 'you are a god, because etc.' He can say 'you are my true son, because you have just won this great victory'. Lachmann (ad loc.) described the crux very well: 'deum autem sese esse inepte nimis hic affirmabat Caesar, cum illud esset potius agendum, Augustum esse verum et dignum patre Caesare prolem.' His own proposal, tum deus does not work, but his diagnosis lead to the solution found by Baehrens. Read tu meus: est (Baehrens). This is one of several cases in this paradosis where a form of deus was smuggled into the text; see above on 3.20.5-6. H. (pp. 460-1) cites Baehrens but prints sum deus, while G. modifies Baehrens' proposal by printing es meus. One could also consider tu meus es. This passage, like 1.5.3 (see above) may show that the emphatic use of meus, mea was misunderstood by scribes.

\subsubsection{1-2 \\ foederis heu taciti cuius fallacia verba non audituri diripuere Noti}

Read pacti (Palmer) for taciti which makes no sense because the words sealing their vows were, if not written, actually spoken by both lovers. This has been explained very well by Goold in HSCP 71, 1966, 68. When Propertius says to Cynthia 'I will love you forever', and she says the same words to him, this is a foedus pactum, but not a foedus tacitum. Whether the gods have heard it or not, is another question. It is simply not true, as F. contends, that foedus tacitum could mean furtivus amor, even though he cites Richard Reitzenstein and Shackleton Bailey. This mixes up two completely different things. The situation in 3.20 (see above) is similar: there we also have a foedus pactum, but this time (after the separation from Cynthia) it is actually written down and formally sealed (vv. 15-8; 21-30). That poem, we should remember, is not addressed to Cynthia but to another woman. Maybe the poet did not trust spoken vows any more and decided to have everything in writing. H. (p. 466) prints pacti, while G. introduces sancti which one recognizes at once as one of his creations.

\subsubsection{7-8}

The woman who melted the golden image of Cynthia is clearly one of her disloyal servants; the distich belongs after $35-40$, the part of the poem which deals with that group (Lygdamus, Nomas), as Schrader saw. The good servants (Petale, Lalage) who are now being treated so badly are the subject of 43-6. The distich lost its place, perhaps because of the homoeoteleuta $\mathrm{hu}$ mum/aurum/meum. Once this is recognized, we also must separate the two groups by at (41) for et, as proposed by Markland. G. and H. keep the vulgate. 


\subsubsection{3-4}

Andromedeque et Hypermestre sine fraude maritae narrant historiae tempora nota suae

There seems to be no need to change pectora ( $\omega)$ to tempora (Ayrmann). What needs to be changed, as Markland saw, are the endings of historiae ... suae. He proposed historias ... suas but kept pectora nota which remains a stumbling block. What Propertius may have written is pectora fida. Cf. Ov. met. 9.248-9, trist. 3.3.48; for the singular, cf. Lucr. 5.864, Hor. carm. 2.12.16, Sen. Thy. 334, Phaedr. 875, Stat. silv. 3.2.99, Theb. 2.364. The emphasis is on the faithfulness of these heroines, as opposed to Clytaemnestra and Pasiphae. I realize that fida is not very close to nota palaeographically, but it certainly fits the context; cf. 3.13.24 fida Euadne ... pia Penelope. In 2.15.28 masculus et totum femina coniugium, Cornelissen very plausibly proposed fidum for totum, and when fidum could become totum, fida could easily be corrupted to nota. Cf. also Hor. carm. 2.12.16 bene mutuis / fidum pectus amoribus; Ov. met. 9.249 (where Bömer's note has to be used with caution). Read perhaps

\section{Andromedeque et Hypermestre, sine fraude maritae, narrant historias, pectora fida, suas.}

The key words in the whole context are fides and perfidia. Andromeda and Hypermestra were faithful wives; this is why there allowed to dwell in a kind of Elysium, while the others, the unfaithful ones, inhabit a less desirable region of the underworld. In [Sen.] Herc. O $947 \mathrm{ff}$ Deianira admits her guilt in Heracles' death and is ready to go to the underworld, but not to the sacred grove reserved to the souls of faithful wives:

\section{claudite Elysium mihi}

quaecumque fidae coniuges nemoris sacri lucos tenetis.

Here we find the word which we miss in the context of Propertius' elegy. For pectora fida a referee furnishes the following parallels: Ov. Met. 9.2489; Tr. 3.3.48; Hor. Carm. 2.12.16; Stat. Theb. 2, 364; Silv. 3.12.99. E. Pasoli, in his edition of Book IV $\left(2^{\text {nd }}\right.$ ed. 1967,69$)$ detected an apposition in the pentameter, comparing 4.1.12, though he kept historiae tempora nota suae. I agree as far as the apposition is concerned; in fact, we have two appositions in this couplet. See above on 2.29.15 and cf. 4.1 .12 pellitos habuit, rustica corda, Patres; Verg. Aen. 2.349 iuvenes, fortissima frustra/ pectora. As a result of some agonizing (p. 471), H. prints sine fraude marita (Heins.)/ narrant historias, foedera (Heins.) nota, suas. G. follows Heinsius and Ayrmann. 


\subsubsection{9-70}

sic mortis lacrimis vitae sanamus amores: celo ego perfidiae crimina multa tuae

Some scholars wanted to change mortis which forms a contrast to vitae, but the real problem is sanamus, it seems (read Sh. Bailey, Propertiana, pp. 252-3). Even though love is often described as a kind of desease, it is not clear how it could be healed by the 'tears of death'. (Does this mean 'the tears shed by the dead' or 'the tears shed over the death of a beloved person'?) Among the proposals made, Rossberg's sancimus is still attractive. The tears we shed when someone we once loved has died prove, indeed, the reality of that love. Cynthia's ghost says this to Propertius, because his great passion for her is now a thing of the past, but the fact that he is still moved to tears proves to her that his feelings for her were sincere, and therefore she forgives him now his perfidia. And Propertius lets us know that he is crying over Cynthia and that he is sure of her forgiveness. Another possibility, solamur (v. 1. ap. Passerat., Broukhus.) could be mentioned, but it is really the one who weeps who need to be comforted, not the love felt long ago. Heinsius' satiamus is worth considering but has not appealed to editors, as far as I can see. H. adopts sancimus, and G. rewrites the line as follows: si (G.) nostris (Otto) lacrimis veteres (Burman) renovamus (G.) amores which is quite ingenuous as a rewrite job.

\subsubsection{3-4 \\ sed procul inclusas audit ridere puellas, lucus ubi umbroso fecerat orbe nemus}

Lucus and nemus here mean the same thing, and lucus fecerat nemus is nonsense, but there has to be a wall to separate the sacred precinct and the young women who serve in it from the outside world. Hence murus ... saepserat (Fontein). The first word of the line was corrupted. We probably have to imagine a circular wall, but we should also consider umbrosum (Fontein), to go with nemus, for umbroso, because it is not likely that the wall cast a shadow over the grove. H. (pp. 487-8) accepts murus ... saepserat and thinks umbrosum possible but not necessary. G. keeps the vulgate, including $a b$ ( $u b i$ is Heinsius' emendation of $a b$ ). I think we should read murus ubi umbrosum saepserat orbe nemus (Fontein).

\subsubsection{3-4}

dumque aries murum cornu pulsabat aeno vinea qua ductum longa tegebat opus,

Cossus ait ... 
A Roman army is preparing to besiege Veii and starts to demolish its city walls. The two actions described in the couplet are simultaneous and connected with each other. They should also be joined syntactically. Read: vineaque inductum (Itali, Volscus). $Q V E$ was read as $Q V A$, and the prefix was ignored. H. (p. 498) prints the humanist conjecture, G. keeps the vulgate created by Lachmann.

\subsection{3-8}

cum semel infernas intrarunt funera leges, non exorato stant adamante viae.

te licet orantem fuscae deus audiat aulae: nempe tuas lacrimas litora surda bibent. vota movent superos: ubi portitor aera recepit, obserat herbosos lurida porta rogos

The whole passage is thoroughly corrupt. Leges intrare is apparently not impossible in Latin, as the quotation from a Christian author in F.'s app. crit. shows, but infernas ... sedes (Heins., Burman, Schrader) would be certainly more idiomatic in Propertius; cf. 3.12.33-4 nigrantisque domos animarum intrasse silentum where domos takes the place of sedes, but the word itself is used by Ov. Ib. 174 quas ... tenet sedes noxia turba coles. In the pentameter, one should consider Heinsius' fores or serae for viae. He later changed his mind, as he did about sedes. Fores could be supported by 1.16.18 quid mihi tam duris clausa taces foribus?; Ov. met. 4.453 carceris ante fores clausas adamante sedebant; Ib. 79-80 quas ... ferunt torto vittatis angue capillis/ carceris obscuras ante sedere fores. Roads cannot really be addressed in prayers, but doors can (see 1.16.15ff; 4.9.31ff). But serae is also attractive; see v. 8 obserat; 26 iaceat tacita laxa catena sera; 4.7.90 errat et abiecta Cerberus ipse sera. If we accept fores (or serae) in v. 4, we should probably also accept limina (Fontein) for litora in v. The two conjectures support each other. Propertius envisions the entrance to the underworld as a huge gate, and the whole scene has been misunderstood in the paradosis. In addition, we need Fruter's exorando for exorato; cf. 3.18.23 exoranda canis tria sunt latrantia colla; Ps.-Quint. decl. 10.19 crudelis et inexorabilis custos.

In vv. 7-8, the poet draws a line between di superi and di inferi. While you are alive, the superi may listen to your prayers, but when you are dead, you have no one to appeal to. Again, we have the image of the porta to the underworld. But how could it possibly bar the access to 'pyres full of herbs'? It bars the access the world of darkness, hence umbrosos $(\Delta)$... locos (Livineius or Markland, apparently from Itali). Herbosos is really just a conjecture in $\mathrm{F}$, and we do not have $\mathrm{N}$ for this part of Propertius. Umbrosas ... domos, proposed by Hemsterhuys (Luciani Opera, ed. Bipont., vol. II, 
p. 516) is, perhaps, even better than umbrosos ... locos; cf. 3.12 .33 nigrantis ... domos animarum ... silentum; Sen. Med. 741 opacam Ditis umbrosi domum; Val. Fl. 1.781 (Alcimede) Stygias ... supremo/ obsecrat igne domos (see Liberman [1997] ad loc.). Again and again, the poet refers to a world beyond our human experience, and he finds new expressions for the kind of reality awaiting us there. H. (pp. 502-5) has an excellent discussion of the passage. In his text, he keeps leges, viae, litora, but he prints exorando (Fruter) and umbrosos ... locos. His interpretation of umbrosi is ingenious and enlightening, and the parallels which he cites (Sen. Med. 741 and Epicedion Drusi 427-8) are, to me, absolutely convincing. G. keeps exorato but accepts sedes, fores, limina, umbrosos ... locos which he translates as 'luoghi tenebrosi'.

\subsubsection{1-2}

et tamen emerui generosos vestis honores, nec mea de sterili facta rapina domo

F. defends generosos, but this seems to be just another case of a wrong adjustment; the ending -osos anticipates the ending of the last word of the line. Turnebus (Adversaria XXIII 7) proposed generosae vestis, and that seems to be the proper term for the stola to which she was entitled. The change proposed by Turnebus was accepted by Koppiers and Burman. She says that she truly deserved the honor of wearing this kind of garment. See Camps' note. (Tony Camps was a fine scholar who, in his own quiet way, did a great deal to emend and elucidate the text). We need a contrast to sterili ... domo. Leumann (ThLL 6.2.1800.56) paraphrases 'generosarum vestis', but compares Ov. hal. 66 hinc generosus honos et gloria maior equorum which is not very helpful. Both G. and H. keep generosos.

Can we draw any conclusions from these random comments? Perhaps we can.

I. They may confirm the impression that the indirect tradition is more likely to preserve what Propertius wrote than the extant MSS. See notes on 2.1.58; 3a.23-4; 3.20.5-6.

II. They may reveal a source of errors that has been described before: the tendency of scribes (or perhaps just one early copyist?) to assimilate the ending of a word in the first half of line (usually a pentameter) to the ending of a word at its very end. This tendency introduces rhymes probably not intended by the poet who, of course, uses the device often enough.

It appears that quite a few lines can be emended by removing 'false correspondences', if I may use the expression. When I saw that H., following Lachmann's hint, (see C., pp. $23 ; 67 ; 303 ; 469$ ) paid careful attention to this phenomenon, I decided to go through the whole Corpus, concentrating on 
such cases. Actually, some of Rossberg's conjectures (1877) indicate that he was also aware of this source of errors. H.'s own list includes: 1.5.20 exclusum ... domum ( $\omega$ : domo Heins.; see Lachmann's note ad loc.); 11.15 amota $(\mathrm{N}$ alii : amoto $\mathrm{P} S$ alii) ... custode puella; 2.13.6 Ismarias ( $\mathrm{N}$ a. c. : Ismaria $\mathrm{N}^{2}$ alii) arte feras; 2.25.26; 4.2.44. He cites further examples from Virgil and Silius Italicus and for Ovid's Amores refers to G. W. Most, in C. Deroux (ed.), Studies in Lat. Lit. and Rom. Hist. (Bruxelles 1979), 365. In Ov. Ib. 525 utque lyrae vates fertur periisse severae, B. W. Häuptli (1996), 279 explains severae as a case of 'enallage', but we should probably read severus.

A systematic search has yielded (besides the cases dealt with above which are: $1.5 .12 ; 6.22 ; 12.16 ; 20.14 ; 2.22$ b. $44 ; 3.2 .7 ; 6.22 ; 12.28)$ the following passages: 2.7.16 magnus ( $\omega$ : magni Schneidewin) Castoris iret equus; 2.12.18 alio traice tela tuo ( $\omega$ : loco $\mathrm{N}$ rec. : tua vel puer Itali); 27.7 rursus et obiectum + fletus + caput esse tumultu $[\mathrm{m}]$ where the dative ending was restored by the Itali; 3.8.2 (possibly); 17.12 (possibly); 18.34 ab humana cessit in astra via ( $\omega$ : vice Baehrens, better than humano [Henry] or humanis [Barber], I think); 21.12 pares ( $\omega$ : pari Heins., very good) ducite sorte vices; 4.1.36 Fidenas longa (-e $\omega$ ) erat isse vias ( $\omega$ : via Itali); 3.34 (uncertain); 5.34 puros ... deos (L P alii : dies $\mathrm{N}$ alii); 11.94 caelibis ad curas nec vacet ulla vias ( $\mathrm{N}$ : via $\mathrm{F} L \mathrm{P}$ alii : dies Santen). Even if I have missed a few instances, the tendency has become pretty clear, I hope.

But it also happens that we may have to restore the 'rhyming effect' by conjecture. Take, e. g., 2.6.20 nutritus durae (Itali : duro w), Romule, lacte lupae. What F. says about 'hy pallage' is hardly relevant, and the passage he cites, 4.4 .54 (quem)... nutrit inhumanae inhumanae dura papilla lupae proves the opposite. See H., C., p. 135 who however prints duro in his OCT. Lac durum would have to be ice-cream or cheese. Another such case 2.31.8 quattuor artifices (Broekhus. : -is $\omega)$, vivida signa, boves where G. accepts the conjecture while $\mathrm{H}$. follows the MSS. In 4.3.8 munitus ( $\omega$ : - o cod. Berol. Lat. 500, Beroaldus ex coni.) + hericus + hostis equo all recent editors accept the change.

It also happens that an ending in the first half of a line influences the ending of the last word, as in 2.16 .29 (see above).

III. H. (C., pp. $213 ; 218 ; 248 ; 390 ; 471 ; 506)$ deals with the so-called enclosed apposition, also known as Schema Cornelianum, a stylistic device which is often misunderstood in this paradosis. This has been noticed, e. g., by Lemaire in his Paris edition (1832), on 3.21.27. Among the passages investigated above, the following seem to be affected by this particular form of misunderstanding: $1.13 .24 ; 2.29 .25 ; 3.19 .22 ; 4.7 .58 ; 64$. H. acknowledges the following cases: 1.16 .8 exclusi[s] signa iacere faces where exclusis was emended in the Itali; one could place exclusi signa between commata; 11.30 Baiae, crimen amoris, aquae; 2.3.14 geminae, sidera nostra, faces; 24.12 manibus dura frigus habere pila where $\mathrm{H}$. accepts my proposal duram 
... pilam; 25.1 unica nata meo pulcherrima cura dolori where H. (pp. 217-8), following Goold, prints Phillimore's Cynthia for unica; 29.3 pueri mihi turba minuta (-i Heins.); 31.8 (see above); 3.3 .31 volucres, mea turba, columbae (reminiscent of Verg. ecl. 1, 57); 19.22 (see above); 4.1 .12 pellitos habuit, rustica corda, Patres; 7.64 (see above); 9.3 venit ad invictos, pecorosa Palatia, montis; 11.15 vos, vada lenta, paludes (where H., C., pp. 506-7 adopts Butrica's Acherontis for paludes). H. refers to J. B. Solodow's valuable paper in: $H S C P$ 90, 1985, 129-53 to which he adds (p. 248) a few more examples.

IV. The first and last words of a line are often corrupt.

V. Forms of deus are introduced into the text by mistake. 
